\title{
Effects of Alexandrium minutum exposure upon physiological and hematological variables of diploid and triploid oysters, Crassostrea gigas
}

\author{
Hansy Haberkorn ${ }^{a}$, Christophe Lambert ${ }^{a}$, Nelly Le Goïc ${ }^{a}$, Marielle Guéguen ${ }^{b}$, Jeanne Moal ${ }^{c}$, Elena \\ Palacios $^{d}$, Patrick Lassus ${ }^{b}$ and Philippe Soudant ${ }^{a, *}$
}

\footnotetext{
${ }^{a}$ Laboratoire des Sciences de l'Environnement Marin, Institut Universitaire Européen de la Mer, Université de Bretagne Occidentale, Place Copernic, Technopôle Brest-Iroise, 29280 Plouzané, France

${ }^{b}$ IFREMER Centre de Nantes, Laboratoire Phycotoxines, BP 21105, 44311 Nantes, France

c IFREMER Centre de Brest, Laboratoire de Physiologie des Mollusques, BP 70, 29280 Plouzané, France

${ }^{d}$ Centro de Investigaciones Biológicas del Noroeste (CIBNOR), La Paz, B.C.S., Mexico
}

*: Corresponding author : Philippe Soudant, Tel.: +33 2984986 23; fax: +33 2984986 45, email address : Philippe.Soudant@univ-brest.fr

\begin{abstract}
:
The effects of an artificial bloom of the toxin-producing dinoflagellate, Alexandrium minutum, upon physiological parameters of the Pacific oyster, Crassostrea gigas, were assessed. Diploid and triploid oysters were exposed to cultured A. minutum and compared to control diploid and triploid oysters fed T. Isochrysis. Experiments were repeated twice, in April and mid-May 2007, to investigate effects of maturation stage on oyster responses to $A$. minutum exposure. Oyster maturation stage, Paralytic Shellfish Toxin (PST) accumulation, as well as several digestive gland and hematological variables, were assessed at the ends of the exposures.

In both experiments, triploid oysters accumulated more PSTs (approximately twice) than diploid oysters. Significant differences, in terms of phenoloxidase activity (PO) and reactive oxygen species (ROS) production of hemocytes, were observed between $A$. minutum-exposed and non-exposed oysters. $\mathrm{PO}$ in hemocytes was lower in oysters exposed to $A$. minutum than in control oysters in an early maturation stage (diploids and triploids in April experiment and triploids in May experiment), but this contrast was reversed in ripe oysters (diploids in May experiment). In the April experiment, granulocytes of oysters exposed to $A$. minutum produced more ROS than those of control oysters; however, in the May experiment, ROS production of granulocytes was lower in A. minutum-exposed oysters. Moreover, significant decreases in free fatty acid, monoacylglycerol, and diacylglycerol contents in digestive glands of oysters exposed to A. minutum were observed. Concurrently, the ratio of reserve lipids (triacylglycerol, ether glycerides and sterol esters) to structural lipids (sterols) decreased upon $A$. minutum exposure in both experiments. Also, several physiological responses to A. minutum exposure appeared to be modulated by maturation stage as well as ploidy of the oysters.
\end{abstract}

Keywords: Oysters; Ploidy; Physiology; Harmful-algal bloom; Alexandrium minutum; PST accumulation 


\subsubsection{Introduction}

Among harmful algae, Alexandrium species are known to produce Paralytic Shellfish Toxins (PSTs), witch are the most widespread shellfish-contaminating biotoxins, with outbreaks occurring worldwide (Huss, 2003). In France, Alexandrium minutum Halim (1960) has been known to bloom in coastal waters since the 1980's (Lassus et al., 1992), especially in North Brittany (English Channel) during summer (Morin et al. 2000).

PSTs are comprised of approximately 20 naturally-occurring biotoxin derivatives that vary widely in specific toxicity (measured by standard mouse bioassay). The basic molecular structure is that of saxitoxin (STX). PSTs are neurotoxins, whose mode of action involves a reversible and highly specific block of sodium channel transport, disabling the action potential of excitable membranes (nerves and muscle fibers) (Narahashi, 1988).

The current EU regulatory limit for human consumption of shellfish is set at $80 \mu \mathrm{g}$ STX eq. $100 \mathrm{~g}^{-1}$ shellfish meat (SM). Considering, however, possible consumption of a large portion (400g) of shellfish, the European Food Safety (EFSA) recently established that the maximum concentration in shellfish meat should be less than $7.5 \mu \mathrm{g}$ STX eq. $100 \mathrm{~g}^{-1}$ SM to avoid exceeding the acute reference dose (ARfD) of $0.5 \mu \mathrm{g}$ STX eq. $\mathrm{kg}^{-1}$ body weight (EFSA Journal, 2009). It is also estimated that $25 \%$ of EU samples compliant with the EU limit exceeded the concentration set by ARfD (EFSA Journal, 2009). The mouse bioassay (AOAC, 1990) protocol is the officially-prescribed method for the evaluation of STX-group toxin contamination. Although MBA sensitivity (37 $\mu \mathrm{g}$ STX eq. $100 \mathrm{~g}^{-1}$ ) allows quantification of STX-group toxins at the current EU regulatory limit, it also detects concentrations compatible with ARfD (EFSA Journal, 2009). Only the HPLC-fluorescence detection method can sensitivity sufficient to quantify STX-group toxins at $1-8 \mu$ g STX eq. $100 \mathrm{~g}^{-1} \mathrm{SM}$.

Several commercially-harvested bivalve species, such as oysters, are known to accumulate PSTs by feeding on phytoplankton PST producers (see review by Bricelj and Shumway, 1998). Bivalves show significant (up to 100-fold) inter-specific differences in accumulation of PSTs, which was inversely correlated with toxin sensitivity (Bricelj and Shumway, 1998). This variability of sensitivity to PSTs appeared to be related to nerve sensitivity in a dosedependant manner. Indeed, Bricelj and Shumway (1998) reported that $10^{-7}$ g.ml ${ }^{-1}$ STX was sufficient to block the action potential of nerves in eastern oysters C. virginica when $10^{-3}$ g.ml

${ }^{1}$ was insufficient to block action potential inblue mussels $M$. edulis. Some bivalve species possessing nerves insensitive to PST (Mytilus edulis) readily feed on toxic cells and thereby accumulate high toxin levels. In contrast, species such as Crassostrea virginica are highly sensitive to PSTs, accumulating fewer toxins and exhibiting physiological and behavioral mechanisms to avoid or reduce exposure to toxic cells (Bricelj and Shumway, 1998). The Pacific oyster $C$. gigas and the soft-shell clam Mya arenaria (two PST-sensitive species) were reported to reduce filtration activity when feeding on PST-containing microalgae (Lassus et al., 2004; Bricelj and Shumway, 1998). Differences in toxin accumulation (up to five times) were also observed between different populations of the same species, $M$. arenaria, and was surmised to be related to nerve sensitivity differences (Bricelj et al., 2005). Indeed, a natural mutation of a single amino acid residue decreasing affinity (1,000-fold) of the saxitoxin- 
binding site in the sodium channel pore, was found to be responsible for the difference in nerve sensitivity between two populations of $M$. arenaria exposed to PST-producing Alexandrium fundyense (Bricelj et al., 2005).

Toxin composition and content in toxigenic microalgae vary greatly according to species or strain and depend also environmental or culture conditions (Hégaret et al., 2009). An A. minutum strain isolated in France can produce 1.5 pg STX eq. cell ${ }^{-1}$ (Lassus et al., 2007); whereas, the same species isolated in New Zealand produced 11 pg STX eq. cell ${ }^{-1}$ (Chang et al., 1997). Chou and co-workers (2004) reported that toxin content of different clones of $A$. minutum isolated in Taiwan varied from 11 pg STX eq. cell ${ }^{-1}$ to 103 pg STX eq. cell ${ }^{-1}$. This variability in algal toxin content has consequences to feeding responses to and toxin accumulation of bivalves exposed to Alexandrium species. Bardouil and co-workers (1993) observed clearance rate in $C$. gigas decreased more drastically when oysters were exposed to A. tamarense (7.2 pg STX eq. cell ${ }^{-1}$ ) than to A. minutum ( 0.5 pg STX eq. cell ${ }^{-1}$ ).When exposed to less-toxic Alexandrium species or strains, sensitive bivalves such as $C$. gigas can feed on and accumulate PSTs (Lassus, unpubl. obs.).

Alexandrium species are also known to produce other toxic compounds, such as ichtyotoxins (Emura et al., 2004) and allelochemicals (Arzul et al., 1999; Tillmann et al., 2008). Ford et al. (2008) tested effects of two A. tamarense strains, PST and non-PST producing, upon Manila clam Ruditapes philippinarum and Mya arenaria hemocytes. This study showed that the nonPST strain had more-negative impacts on hemocytes (decreased adhesion and phagocytosis) compared to the PST-producing strain of A. tamarense (Ford et al., 2008). Based upon biological effects of Alexandrium exposure clearly unrelated to PSTs, one can speculate that effects of PSTs and other toxic compounds/molecules may also result in damage to organs and physiological processes other than muscles. Considering this, Alexandrium effects upon nerves and muscles of exposed bivalves can be linked to PSTs, but there appear to be responses to other compounds not clearly identified.

Aside from toxin accumulation and associated human health issues, there is some concern about the impact of A. minutum exposure on the physiology and health of $C$. gigas. Furthermore, the physiological status of animals may also feed-back to rates of toxin accumulation and effects during $\mathrm{HAB}$ exposure.

Li et al. (2002) studied the effect of Alexandrium tamarense (PST-containing strain) on bioenergetics and growth rate of the clam Ruditapes phillipinarum and the mussel Perna viridis. High concentrations of toxic $A$. tamarense (resulting in high PST burdens in the tissues) decreased clearance rate of the clam but not of the mussel. Absorption efficiency, however, decreased for both species with diets containing PST, which resulted in a reduction in energy budget. HABs occurring during specific stages of reproduction could be another major factor affecting oysters, in terms of energy budget. In C. gigas, energy balance (evaluated through scope for growth methods) has been demonstrated to decrease as gametogenesis progresses, resulting in a negative scope for growth (Lambert et al., 2008). The digestive gland plays an obvious, major role in nutrient digestion and assimilation, as digestive-enzyme activities in bivalves can be affected by nutritional condition. Indeed, changes in enzymatic activities are 
mechanisms used by bivalves to optimize energy gain when experiencing variation in dietary input (Fernández-Reiriz et al., 2001; Labarta et al., 2002).The mussel M. chilensis can, indeed, use toxic microalgae (Alexandrium catenella) as a food source by adjusting carbohydrase activities (amylase, laminarinase and cellulase) and absorption mechanisms (Fernández-Reiriz et al., 2008). It is, thus, pertinent to assess digestive-enzyme activities in bivalves exposed to toxic microalgae. Moreover, the digestive gland is also involved in energy storage, preferentially as lipids (Soudant et al., 1999). As HABs are likely to impact digestive-gland structure and functions, it appears prudent to assess how HABs could modulate quantities of individual lipid classes involved in energy storage in this organ. Moreover, the digestive gland is the organ accumulating the most toxins compared to other tissues in bivalves (Bricelj and Shumway, 1998).

In bivalves, one line of defense to noxious, harmful or pathogenic agents resides in circulating cells called hemocytes that are similar to white blood cells in vertebrates (Cheng, 1996). Concerning hemocyte variables, Hégaret et al. (2007a, 2007b, 2008) reported that harmfulalgal exposure can modulate cellular immune components and functions of bivalves. Moreover, Galimany et al. (2008) observed an inflammatory response in the stomach of Mytilus edulis exposed to $A$. fundyense. These findings indicate that the bivalve immune system can be activated by certain harmful algae, or conversely can be suppressed. The reproductive period is also associated with changes in hemocyte variables; some are depressed in C. gigas during gametogenesis, specifically hemocyte concentration, phagocytosis, and adhesion (Lambert et al., 2008). During gametogenesis, hemocytes in triploid oysters were found to have higher phagocytic, esterase and peroxidase activities than those of diploids (Gagnaire et al., 2006). These differences were attributed to the reduced gametogenic development of the triploids.

Indeed, triploid oysters are increasingly used for aquaculture because they can be marketed during summer when diploid oysters are fully-ripe and not appreciated by consumers. It is unknown, however, how triploidy may affect toxin accumulation.

The purpose of the present study was to determine the effects of an artificial bloom of the toxin-producing dinoflagellate, Alexandrium minutum (strain AM89BM), upon digestive parameters, and hemocyte and plasma variables of the Pacific oyster, Crassostrea gigas. Diploid and triploid oysters were compared to assess any differences in toxin accumulation and physiological responses to harmful-algal exposure. Experiments were conducted at two different periods (one month apart), using the same oyster stock, to obtain a gradient of gonad maturation. After 4 days of exposure to A. minutum or Isochrysis sp. (clone Tahitian T.Iso) as a non-toxic control, toxin accumulation, reserve lipid classes and amylase activities, humoral phenoloxidase variables, hemolyse/agglutination capacity, and hemocyte concentration, morphology, viability, phagocytosis activity, reactive oxygen species production and phenoloxydase activity, were measured. 


\subsubsection{Materials and methods}

\section{Oysters}

Diploid and triploid Pacific oysters, Crassostrea gigas, used in the two experiments were obtained from an oyster producer at île de Kerner (Morbihan, FRANCE) and belong to the same commercial stocks (20-21 months old). For each experiment, we used 60 diploid oysters and 60 triploid oysters. In April, flesh dry weight was $1.22 \pm 0.12 \mathrm{~g}$ and $0.90 \pm 0.09 \mathrm{~g}$ in diploids and triploids, respectively. In May, flesh dry weight was $1.33 \pm 0.14 \mathrm{~g}$ and $0.98 \pm$ $0.09 \mathrm{~g}$ in diploids and triploids, respectively. At both collection times, three pools of four oysters (for each ploidy) were confirmed to be free of PST contamination (no detectable levels of PSTs by IP-HPLC analysis).

\section{Algal culture}

Alexandrium minutum (strain AM89BM) was grown in 10-liter batch culture using autoclaved seawater filtered to $1 \mu \mathrm{m}$ and supplemented with L1 medium (Guillard and Hargraves, 1993). Cultures were maintained at $16 \pm 1^{\circ} \mathrm{C}$ and $100 \mu \mathrm{mol}$ photon. $\mathrm{m}^{-2} \cdot \mathrm{s}^{-1}$, with a dark:light cycle of 12:12h. A. minutum was harvested after 12 days, still in exponential growth phase under our conditions. At this age, this strain produced $1.3 \pm 0.1 \mathrm{pg}$ STX eq. per cell (measured by the method of Oshima (1995)).

Isochrysis sp., clone Tahitian (T.Iso), cultures were obtained from the Argenton hatchery (IFREMER - France). Cultures were produced in 300-liter cylinders containing 1- $\mu \mathrm{m}$ filtered seawater enriched with Conway medium at $24 \pm 1{ }^{\circ} \mathrm{C}$, air- $-\mathrm{CO}_{2}(3 \%)$ mix aerated, and with continuous light. T.Iso was harvested in the exponential growth phase (6-8 days) for the feeding experiments.

\section{Experimental design of $A$. minutum exposures}

For each experiment (April and May), 120 oysters (60 diploids and 60 triploids) were placed haphazardly in twelve 15-L tanks (10 oysters per tank). Oysters were acclimated for 10 days with continuous flow of $14 \mathrm{ml} \cdot \mathrm{min}^{-1}$ of seawater (filtered to $0.5 \mu \mathrm{m}$ ) with T.Iso at $5.10^{5}$ cells.ml $l^{-1}$ at $16 \pm 1^{\circ} \mathrm{C}$. After acclimation, diploid and triploid oysters were fed continuously for 4 days at $14 \mathrm{ml} . \mathrm{min}^{-1}$ with $5.10^{5}$ cells. $\mathrm{ml}^{-1}$ of T.Iso (6 control tanks with diploids and triploids) and with $5.10^{3}$ cells.ml ${ }^{-1}$ of $A$. minutum (equivalent to $6.5 \mathrm{ng}$ STX eq. - 6 treatment tanks with diploids and triploids).

\section{Oyster sampling}

At the end of the algal-exposure, all oysters were sampled and distributed as follow. For each tank (10 oysters), gonads of two oysters were used for histological analysis of maturation stage. Pooled digestive glands of four oysters were used to measure toxins, reserve lipid contents, and amylase activity. Four oysters were used for individual plasma and hemocyte variable measurements and condition index. 


\section{Qualitative analysis of maturation stages}

Gonads were dissected and transferred into Bouin fixative (for $48 \mathrm{~h}$ ). Fixed gonads were dehydrated in ascending ethanol solutions, cleared with xylene and embedded in paraffin wax. Five-micrometer thick sections were cut, mounted on glass slides, and stained with Harry's hematoxylin-Eosin Y (Martoja et al., 1967). Slides were examined under a light microscope to determine gametogenic stage according to the reproductive scale reported by Mann (1979). In this scale, four stages are defined: stage 0 (inactive), stage 1 (early gametogenesis), stage 2 (late gametogenesis) and stage 3 (ripe).

\section{Condition index}

To assess oyster-flesh dry weight, soft tissues were removed from shells and placed in a preweighed aluminum cup. Shell and flesh were dried for $48 \mathrm{~h}$ at $70^{\circ} \mathrm{C}$ and then weighed. Condition index of individual oysters was then calculated as described previously (Lucas and Beninger, 1985), following the formula: dry flesh weight / dry shell weight x 100

\section{Digestive gland variables}

Just after dissection, digestive glands were immediately frozen in liquid nitrogen, weighed, pooled ( 1 pool of 4 digestive glands per tank), and stored at $-80^{\circ} \mathrm{C}$ until analysis. Later on, pools were ground with a "Dangoumau" homogenizer into liquid nitrogen and divided for three different analyses.

\section{Toxin content}

One gram of ground digestive gland was extracted in $2 \mathrm{ml}$ of $0.1 \mathrm{~N} \mathrm{HCl}(2 \mathrm{v} / \mathrm{w})$ at $4^{\circ} \mathrm{C}$. After centrifugation $\left(3,000 \times \mathrm{g}, 15 \mathrm{~min}, 4^{\circ} \mathrm{C}\right)$, the $\mathrm{pH}$ of extracts was adjusted. If above 3.0 , $\mathrm{pH}$ was adjusted to 3.0 with $12 \mathrm{~N} \mathrm{HCl}$. After half-dilution, supernatants were ultra-filtered (20 kDa, Sartorius Centrisart) and stored at $4^{\circ} \mathrm{C}$ until analysis. PSTs were analyzed by ion-pairing, high-performance liquid chromatography (IPHPLC) according to the method of Oshima (1995). The molar concentration ( $\mu$ mol..$^{-1}$ ) was converted into $\mu$ g STX eq. $100 \mathrm{~g}^{-1}$ of digestive gland by using the conversion factors of Oshima (1995). Results were expressed in $\mu$ g STX eq. $100 \mathrm{~g}^{-1}$ of digestive gland wet weight.

\section{Reserve lipid content}

Ground digestive gland (250 mg) were extracted in $6 \mathrm{ml}$ of Folch solution (chloroform:methanol 2:1). Lipid classes were analyzed by high-performance, thin-layer chromatography (HPTLC) on HPTLC glass plates $(1,010 \mathrm{~mm})$ pre-coated with silica gel 60 from Merck (Darmstadt, Germany). A preliminary run was carried out to remove possible impurities using hexane:diethyl ether (1:1), and the plate was activated for $30 \mathrm{~min}$ at $110^{\circ} \mathrm{C}$. Lipid samples $(4 \mu \mathrm{l})$ were spotted on the plates by the CAMAG automatic sampler. The neutral lipids were separated using a double development with hexane:diethyl ether:acetic acid (20:5:0.5) as first solvent system followed with hexane:diethyl ether (93:3) as a second solvent system. Lipid classes appeared as black bands after dipping plates in a cupric-sulfate, phosphoric-acid solution and heating for $20 \mathrm{~min}$ at $160^{\circ} \mathrm{C}$ (charring). Seven neutral lipid 
classes (categorized as storage lipids: free fatty acids, sterol esters, glycerid ethers, monoacylglycerol, diacylglycerol and triacylglycerol; considered as structural lipids: sterols) were identified based upon standard (Sigma-Aldrich, France) and coloring techniques. The charred plates were read by scanning at $370 \mathrm{~nm}$, and black bands were quantified by Wincats software. Results were expressed as mg of each identified neutral lipid class per $g$ of digestive gland wet weight.

\section{Amylase activity}

Ground digestive gland (200 mg) was homogenized in $1 \mathrm{ml}$ of distilled water and $200 \mu \mathrm{l}$ of this solution were added to $10 \mu \mathrm{l}$ of $0.5 \mathrm{M} \mathrm{CaCl}_{2}$ solution before analysis to assess amylase activity. Amylase activity was then assayed by determination of starch hydrolysis according to the iodine reaction (Samain et al., 1977) modified by Le Moine et al. (1997). One unit of alpha-amylase was defined as the amount of enzyme that degrades $1 \mathrm{mg} \cdot \mathrm{min}^{-1}$ starch at $45^{\circ} \mathrm{C}$.

To assess specific activities, total proteins were determined using the BCA Protein Assay (Biorad). For protein extraction, $200 \mu \mathrm{l}$ of the above solution were added to $200 \mu \mathrm{l}$ of $2 \mathrm{~N}$ $\mathrm{NaOH}$ solution. Protein analysis was carried out on $10 \mu \mathrm{l}$ of $1 / 10$ diluted samples according to the manufacturer's description. Briefly, $200 \mu \mathrm{l}$ of dye reagent was added to $10 \mu \mathrm{l}$ of sample, incubated at $37^{\circ} \mathrm{C}$ for 1 hour and the absorbance was measured at $595 \mathrm{~nm}$. Sample ODs were compared to a standard curve of Bovine Serum Albumin (BSA), and results were expressed as mg of protein. $\mathrm{ml}^{-1}$. Amylase activity was expressed as UI of amylase activity per mg of total protein (specific activity).

\section{Hemolymph variables}

\section{Hemolymph sampling}

Hemolymph was withdrawn from individual oysters using a $1 \mathrm{ml}$ plastic syringe fitted with a 25-gauge needle inserted through a notch made adjacent to the adductor muscle just prior to bleeding. All hemolymph samples were examined microscopically for contamination (e.g., gametes, tissue debris) and then stored in micro-tubes held on ice. As recommended by flow cytometer (FCM) manufacturer, all samples were filtered through $80 \mu \mathrm{m}$ mesh prior to analysis to eliminate any large debris $(>80 \mu \mathrm{m})$ which could potentially clog the flow cytometer. Three hundred microliters ( 3 measures x $100 \mu$ ) of each hemolymph sample were used to measure hemocyte variables by flow cytometry. The remaining hemolymph was separated into cellular (hemocytes) and supernatant (plasma) fractions by centrifugation $\left(800 \times \mathrm{g}, 5 \mathrm{~min}, 4^{\circ} \mathrm{C}\right)$ prior to freezing $\left(-20^{\circ} \mathrm{C}\right)$. These samples then were used to measure biochemical hemocyte and plasma variables (protein content, phenol-oxydase activity and hemolysis/agglutination titers). Methods for measuring cellular (hemocyte) and humoral (plasma) variables are described hereafter.

\section{Measurements of hemocyte variables by flow cytometry}

Characterization of hemocyte sub-populations, number and functions were performed using a FACScalibur (BD Biosciences, San Jose, CA USA) flow cytometer (FCM) equipped with a $488 \mathrm{~nm}$ argon laser. Two kinds of hemocyte variables were evaluated by FCM: descriptive 
variables (hemocyte viability and total and hemocyte sub-population counts), and functional variables (phagocytosis and reactive oxygen species (ROS) production). Analyses were done as described below.

\section{Descriptive variables: Hemocyte viability, total and hemocyte sub-population counts}

These variables were measured individually on hemolymph samples (4 individuals per tank). An aliquot of $100 \mu \mathrm{l}$ of hemolymph from an individual oyster was transferred into a tube containing a mixture of Anti-Aggregant Solution for Hemocytes, AASH (Auffret and Oubella, 1995) and filtered sterile seawater (FSSW), $200 \mu \mathrm{l}$ and $100 \mu \mathrm{l}$ respectively. Hemocyte DNA was stained with two fluorescent DNA/RNA specific dyes, SYBR Green I (Molecular probes, Eugene, Oregon, USA, 1/1000 of the DMSO commercial solution), and propidium iodide (PI, Sigma, St Quentin Fallavier, France, final concentration of $10 \mu \mathrm{g} . \mathrm{ml}^{-1}$ ) in the dark at $18^{\circ} \mathrm{C}$ for 120 minutes before flow-cytometric analysis. PI permeates only hemocytes that lose membrane integrity and are considered to be dead cells; whereas, SYBR Green I permeates both dead and live cells. SYBR Green and PI fluorescences were measured at 500-530 nm (green) and at 550-600 nm (red), respectively, by flow-cytometry. Thus, by counting the cells stained by PI and cells stained by SYBR Green, it was possible to estimate the percentage of viable cells in each sample. All SYBR Green-stained cells were visualized on a Forward Scatter (FSC, size) and Side Scatter (SSC, cell complexity) cytogram. Three sub-populations were distinguished according to size and cell complexity (granularity). Granulocytes are characterized by high FSC and high SSC, hyalinocytes by high FSC and low SSC, while agranulocytes have low FSC and SSC. Total hemocyte, granulocyte, hyalinocyte, and agranulocyte concentrations estimated from the flow-rate measurement of the flowcytometer (Marie et al., 1999) as all samples were run for $30 \mathrm{sec}$. Results were expressed as number of cells per milliliter of hemolymph.

\section{Functional variables}

These variables were measured individually on hemolymph samples, for each condition.

\section{$\underline{\text { Phagocytosis }}$}

An aliquot of $100 \mu \mathrm{l}$ hemolymph, diluted with $100 \mu \mathrm{l}$ of FSSW, was mixed with $30 \mu \mathrm{l}$ of YG, 2.0- $\mu \mathrm{m}$ fluoresbrite micro-spheres, diluted to $2 \%$ in FSSW (Polysciences, Eppelheim, Germany). After 120 minutes of incubation at $18^{\circ} \mathrm{C}$, hemocytes were analyzed at 500-530 nm by flow cytometry to detect hemocytes containing fluorescent beads. The percentage of phagocytic cells was defined as the percentage of hemocytes that had engulfed three or more beads (Delaporte et al., 2003).

\section{Reactive oxygen species production}

Reactive oxygen species (ROS) production by untreated hemocytes was measured using 2'7'dichlorofluorescein diacetate, DCFH-DA (Lambert et al., 2003). A 100- $\mu \mathrm{l}$ aliquot of pooled hemolymph was diluted with $300 \mu \mathrm{l}$ of FSSW. Four $\mu \mathrm{l}$ of the DCFH-DA solution (final concentration of $0.01 \mathrm{mM}$ ) was added to each tube maintained on ice. Tubes were then incubated at $18^{\circ} \mathrm{C}$ for 120 minutes. After the incubation period, DCF fluorescence, 
quantitatively related to the ROS production of untreated hemocytes, was measured at 500$530 \mathrm{~nm}$ by flow-cytometry. Results are expressed as the geometric-mean fluorescence (in arbitrary units, AU) detected in each hemocyte sub-population.

\section{Biochemical hemocyte and plasma variables}

\section{Hemolycyte and plasma phenoloxidase activities}

Plasma samples were thawed on ice, and $100 \mu \mathrm{l}$ of each was transferred in ninety-six-well plates. For hemocytes, cells were suspended in $100 \mu \mathrm{l}$ of FSSW and frozen and thawed on ice tree times successively. Phenoloxidase activity was measured as described by Reid (2003). Briefly, $50 \mu \mathrm{l}$ of Tris-HCl buffer $(0.2 \mathrm{M}, \mathrm{pH}=8)$ and $100 \mu \mathrm{l}$ of l-DOPA (20 mM, L-3,4dihydrophenyl-alanine, Sigma D9628) were added to each well. The micro-plate was rapidly mixed for $10 \mathrm{~s}$. The reaction was then measured at ambient temperature, with color change recorded every $5 \mathrm{~min}$, at $492 \mathrm{~nm}$, over a period of $1 \mathrm{~h}$. The micro-plate was mixed prior to each measurement. Two controls, without sample but containing l-DOPA and Tris-SDS buffer, were measured in parallel, and these values were subtracted from test values to correct for possible auto-oxidation of the l-DOPA.

To access phenoloxidase specific activity, protein analysis was carried out as described for digestive glands (see paragraph 2.6.3), except that proteins were not extracted with $\mathrm{NaOH}$ and samples were not diluted. Results were expressed as phenoloxidase-specific activity

\section{Agglutination and hemolysis titers in plasma}

Agglutination titer (indicative of the presence of lectins) and hemolysis titer (indicative of red blood cell lysis factors) were measured on a sub-sample of plasma (supernatant) fraction. Quantification of agglutination titer was performed according to the protocol from Barracco et al. (1999), using horse red blood cells. Briefly, 50- $\mu$ l plasma samples were added to U-shaped wells of 96-well-microtiter plates, and a two-fold, serial dilution (pure solution to 1/2 dilution) was prepared using Tris-buffered saline (containing $0.15 \mathrm{M} \mathrm{NaCl}$ ). The same volume of a $2 \%$ suspension of horse red blood cells in TBS was added to each well and incubated for $3 \mathrm{~h}$ at room temperature. In controls, oyster plasma was replaced with TBS. Agglutination titer and hemolysis titer were expressed as the log (base 2) of the reciprocal of the highest dilution showing a positive pattern of agglutination or hemolysis of red cells, respectively.

\section{Statistical analysis}

Differences between experiments (April and May) were assessed using Student's T-test. Results of each experiment were analyzed statistically using Mulifactor-ANOVA (MANOVA) for each physiological parameter and hemocyte variable as the dependent variable, and feeding treatment and ploidy as independent variables. Whenever a clear trend appeared on the graphs, a Student's T-test was also used within ploidy groups to assess differences linked to dietary treatment for a dependent variable. We used Statgraphics Plus statistical software (Manugistics, Inc, Rockville, MD, USA). Results were considered significant when the $\mathrm{P}$-value was $<0.05$. 


\subsubsection{Results}

\section{Gonad maturation stages}

Oysters fed T.Iso and A. minutum were combined to assess oyster gonad maturation (Figure 40). Maturation of both diploid and triploid oysters was more advanced during the May experiment than during April. In both experiments, triploids were less mature than diploids. Oyster groups in both experiments can be classified according to gonad maturation stage (from less mature to more mature) first were triploids in April, triploids in May, then diploids in April, and at last diploids in May.

A

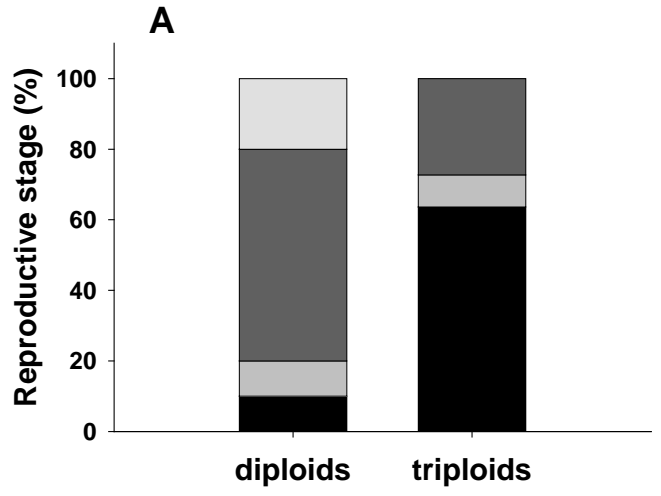

B

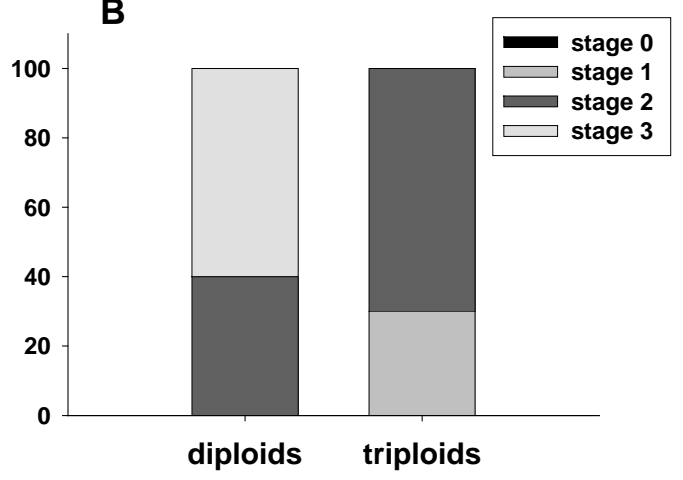

Figure 40 - Oyster maturation stages (expressed as $\%, n=12$ oysters) according to ploidy in April (A) and May (B) experiments, regardless of dietary conditioning (T.Iso or A. minutum).

Triploids in the April experiment were mostly at the undifferentiated stage, and one third were in early and late gametogenesis; triploids in the May experiment were in early and late gametogenesis, diploids in the April experiment were dominated by late gametogenesis with 20\% mature oysters; and finally, diploids in the May experiment were mainly (60\%) observed to be sexually mature while $40 \%$ were in late gametogenesis.

\section{Wet weight of digestive gland and condition index}

There was no significant difference, in term of condition index (CI), attributable to diet or ploidy in both experiments (Tableau 8). Whole-oyster dry weight (DW) was significantly higher in diploid oysters than in triploid oysters for both experiments (in April p=0.0045 and in May $\mathrm{p}=0.0021$, MANOVA). DW of both diploid and triploid oysters did not change significantly between the two experiments. Wet weights (WW) of digestive glands were similar in the April experiment regardless of diet or ploidy. In the May experiment, mean WW of digestive gland was significantly higher in diploids than in triploids. Exposure to $A$. minutum in this experiment resulted in a significant decrease in digestive gland WW compared to T.Iso feeding. A significant interaction between ploidy and diet was also noted; lower digestive gland WW was found in triploid oysters exposed to A. minutum. 
Tableau 8 - Oyster condition index, body dry weight and digestive gland wet weight according to ploidy and microalgal exposure, in April and May experiments. This table also includes the results of the MANOVAs testing ploidy and microalgal exposure effects separately in both experiments.

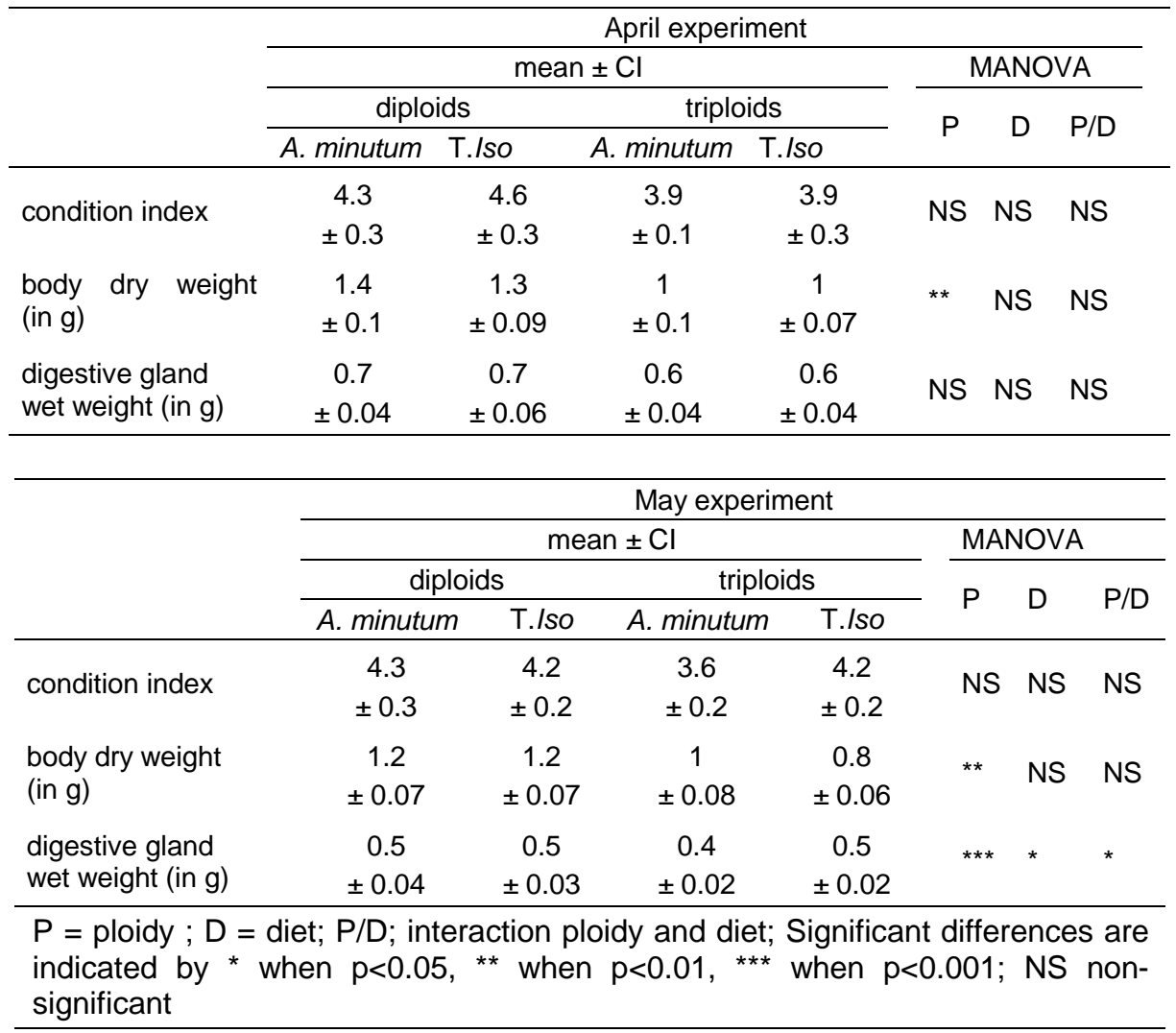

\section{Toxin content}

PST content in digestive gland was significantly higher in May than in April ( $\mathrm{p}=0.003$, T-test). In both experiments, triploid oysters accumulated more toxin (about twice) than diploids (Figure 41); April experiment $\mathrm{p}=0.032$ and May experiment $\mathrm{p}=0.047$, T-test). Concomitantly, A. minutum cells were observed in digestive gland and bio-depots.
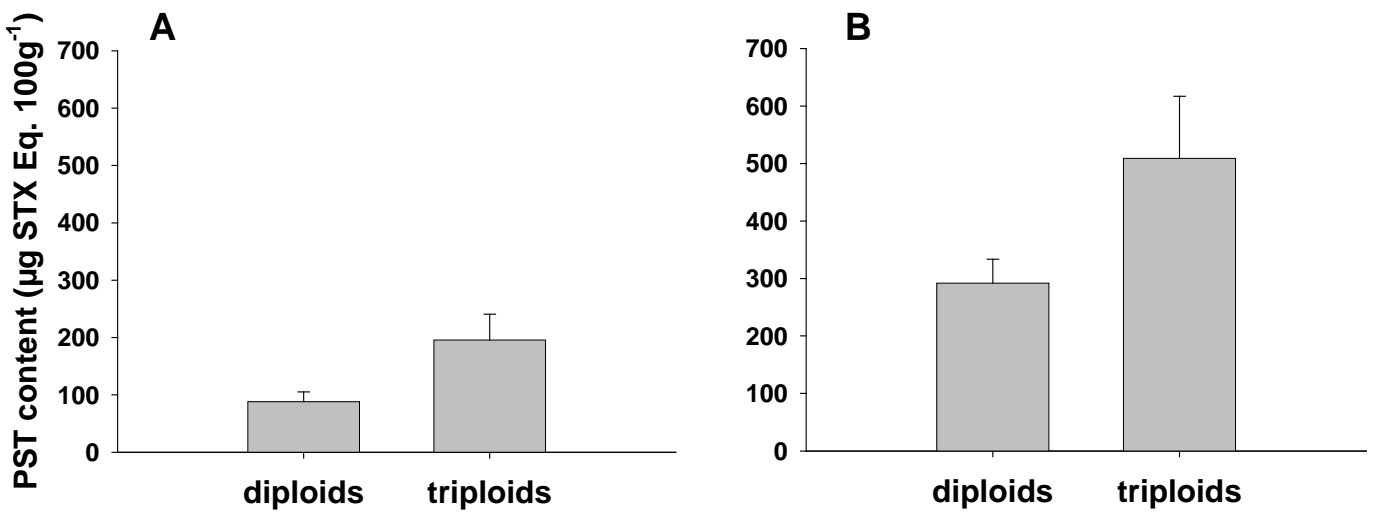

Figure 41 - PST content (mean of 3 pools of 4 oysters each, in $\mu \mathrm{g}$ STX eq. $100 \mathrm{~g}^{-1}$ of tissue wet weight, \pm $\mathrm{Cl}$ ) in digestive glands of diploid and triploid oysters exposed to $A$. minutum in April $(\mathrm{A})$ and May $(\mathrm{B})$ experiments. 


\section{Digestive gland parameters}

\section{Reserve lipid content}

Neutral lipid classes detected in digestive glands were free fatty acids, sterol esters, ether glycerides, sterols, monoacylglycerols, diacylglycerols and triacylglycerols (Tableau 9). A reserve/structure ratio was determined as the ratio between reserve lipids (sterol ester + glycerid ether + triacylglycerol content) and a structural lipid (sterol content). 
Tableau 9 - Neutral lipid class contents (expressed as $\mathrm{mg} \cdot \mathrm{g}^{-1}$ of tissue wet weight) in oyster digestive glands according to ploidy and microalgal exposure, in April and May experiments. This table also includes the results of the MANOVAs testing ploidy and microalgal exposure effects separately in both experiments.

\begin{tabular}{|c|c|c|c|c|c|c|c|}
\hline & \multicolumn{7}{|c|}{ April experiment } \\
\hline & \multicolumn{4}{|c|}{ mean $\pm \mathrm{Cl}$} & \multicolumn{3}{|c|}{ MANOVA } \\
\hline & \multicolumn{2}{|c|}{ diploids } & \multicolumn{2}{|c|}{ triploids } & \multirow{2}{*}{$\mathrm{P}$} & \multirow{2}{*}{$\mathrm{D}$} & \multirow{2}{*}{ P/D } \\
\hline & A. minutum & T.Iso & A. minutum & T.Iso & & & \\
\hline monoacylglycerols & $\begin{array}{c}0.3 \\
\pm 0.02\end{array}$ & $\begin{array}{c}0.6 \\
\pm 0.04\end{array}$ & $\begin{array}{c}0.2 \\
\pm 0.00\end{array}$ & $\begin{array}{c}0.6 \\
\pm 0.03\end{array}$ & NS & $\star * *$ & NS \\
\hline diacylglycerols & $\begin{array}{c}0.3 \\
\pm 0.04\end{array}$ & $\begin{array}{c}0.4 \\
\pm 0.06\end{array}$ & $\begin{array}{c}0.2 \\
\pm 0.03\end{array}$ & $\begin{array}{c}0.4 \\
\pm 0.01\end{array}$ & NS & * & NS \\
\hline sterols & $\begin{array}{c}2.1 \\
\pm 0.06\end{array}$ & $\begin{array}{c}1.9 \\
\pm 0.07\end{array}$ & $\begin{array}{r}2.06 \\
\pm 0.1\end{array}$ & $\begin{array}{c}1.8 \\
\pm 0.2\end{array}$ & NS & NS & NS \\
\hline free fatty acids & $\begin{array}{c}0.5 \\
\pm 0.03\end{array}$ & $\begin{array}{c}0.7 \\
\pm 0.04\end{array}$ & $\begin{array}{c}0.6 \\
\pm 0.06\end{array}$ & $\begin{array}{c}0.7 \\
\pm 0.08\end{array}$ & NS & * & NS \\
\hline triacylglycerols & $\begin{array}{r}13.1 \\
\pm 1.5\end{array}$ & $\begin{array}{r}12.5 \\
\pm 1.5\end{array}$ & $\begin{array}{c}9.8 \\
\pm 0.9\end{array}$ & $\begin{array}{r}14.6 \\
\pm 0.2\end{array}$ & NS & NS & NS \\
\hline ether glycerides & $\begin{array}{c}1.4 \\
\pm 0.2\end{array}$ & $\begin{array}{c}1.3 \\
\pm 0.2\end{array}$ & $\begin{array}{r}1.04 \\
\pm 0.1\end{array}$ & $\begin{array}{r}2.07 \\
\pm 0.3\end{array}$ & NS & NS & NS \\
\hline sterol esters & $\begin{array}{c}0.3 \\
\pm 0.01\end{array}$ & $\begin{array}{c}0.3 \\
\pm 0.01\end{array}$ & $\begin{array}{c}0.2 \\
\pm 0.05\end{array}$ & $\begin{array}{c}0.2 \\
\pm 0.01\end{array}$ & NS & NS & NS \\
\hline \multirow[t]{5}{*}{ ratio reserve/structural } & $\begin{array}{c}6.9 \\
\pm 0.7\end{array}$ & $\begin{array}{c}7.4 \\
\pm 0.9\end{array}$ & $\begin{array}{r}5.01 \\
\pm 0.9\end{array}$ & $\begin{array}{c}9.6 \\
\pm 0.6\end{array}$ & NS & * & NS \\
\hline & \multicolumn{7}{|c|}{ May experiment } \\
\hline & \multicolumn{4}{|c|}{ mean $\pm \mathrm{Cl}$} & \multicolumn{3}{|c|}{ MANOVA } \\
\hline & \multicolumn{2}{|c|}{ diploids } & \multicolumn{2}{|c|}{ triploids } & P & D & R/P \\
\hline & A. minutum & T.Iso & A. minutum & T.Iso & $P$ & D & PID \\
\hline monoacylglycerols & $\begin{array}{c}0.1 \\
\pm 0.02\end{array}$ & $\begin{array}{c}0.6 \\
\pm 0.05\end{array}$ & $\begin{array}{c}0.1 \\
\pm 0.00\end{array}$ & $\begin{array}{c}0.4 \\
\pm 0.07\end{array}$ & NS & $\star \star \star *$ & NS \\
\hline diacylglycerols & $\begin{array}{c}0.1 \\
\pm 0.02\end{array}$ & $\begin{array}{c}0.2 \\
\pm 0.01\end{array}$ & $\begin{array}{c}0.1 \\
\pm 0.00\end{array}$ & $\begin{array}{c}0.2 \\
\pm 0.05\end{array}$ & NS & * & NS \\
\hline sterols & $\begin{array}{c}1.6 \\
\pm 0.1\end{array}$ & $\begin{array}{c}1.5 \\
\pm 0.2\end{array}$ & $\begin{array}{c}0.9 \\
\pm 0.1\end{array}$ & $\begin{array}{c}0.9 \\
\pm 0.08\end{array}$ & * & NS & NS \\
\hline free fatty acids & $\begin{array}{c}0.5 \\
\pm 0.03\end{array}$ & $\begin{array}{c}0.8 \\
\pm 0.03\end{array}$ & $\begin{array}{c}0.5 \\
\pm 0.03\end{array}$ & $\begin{array}{c}0.7 \\
\pm 0.04\end{array}$ & NS & * & NS \\
\hline triacylglycerols & $\begin{array}{c}9.9 \\
\pm 1.2\end{array}$ & $\begin{array}{c}14.6 \\
\pm 1\end{array}$ & $\begin{array}{c}3.5 \\
\pm 0.08\end{array}$ & $\begin{array}{c}4.2 \\
\pm 0.8\end{array}$ & $\star \star$ & NS & NS \\
\hline ether glycerides & $\begin{array}{c}0.8 \\
\pm 0.1\end{array}$ & $\begin{array}{c}1.6 \\
\pm 0.2\end{array}$ & $\begin{array}{c}0.2 \\
\pm 0.02\end{array}$ & $\begin{array}{c}0.4 \\
\pm 0.1\end{array}$ & NS & NS & NS \\
\hline sterol esters & $\begin{array}{c}0.4 \\
\pm 0.00\end{array}$ & $\begin{array}{c}0.5 \\
\pm 0.05\end{array}$ & $\begin{array}{c}0.1 \\
\pm 0.01\end{array}$ & $\begin{array}{c}0.2 \\
\pm 0.02\end{array}$ & $\star \star *$ & NS & NS \\
\hline ratio reserve/structural & $\begin{array}{r}7.09 \\
\pm 0.6\end{array}$ & $\begin{array}{r}11.2 \\
\pm 0.5\end{array}$ & $\begin{array}{c}4.4 \\
\pm 0.6\end{array}$ & $\begin{array}{c}5.1 \\
\pm 0.9\end{array}$ & * & NS & NS \\
\hline
\end{tabular}

$\mathrm{P}=$ ploidy ; $\mathrm{D}=$ diet; P/D; interaction ploidy and diet; Significant differences are indicated by * when $p<0.05$, ** when $p<0.01$, *** when $p<0.001$; NS non-significant 
In both experiments, monoacylglycerol, diacylglycerol and free fatty-acid contents (Figure 42) were significantly lower in both diploid and triploid oysters fed A. minutum as compared to those fed T.Iso (Tableau 9). In May, contents of sterols, triacylglycerols, and sterol esters, as well as the reserve/structure ratio, were higher in diploids than in triploids.
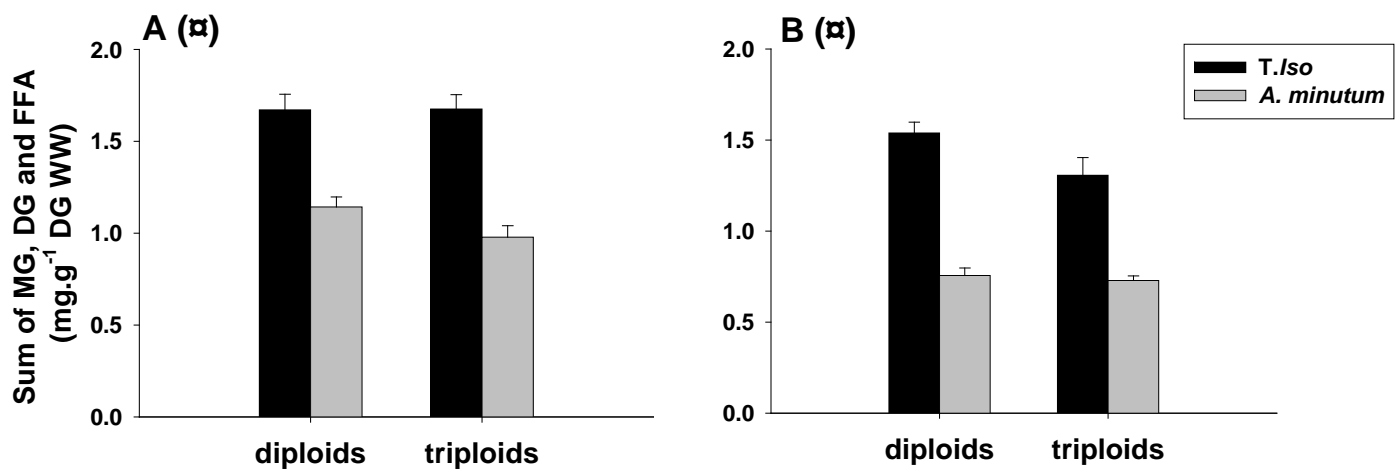

Figure 42 - Sum of monoacylglycerol (MG), diacylglycerol (DG) and free fatty acid (FFA) contents (mean of 3 pools of 4 oysters each, in $\mathrm{mg} \cdot \mathrm{g}^{-1}$ of tissue wet weight, $\pm \mathrm{Cl}$ ) in oyster digestive glands according to ploidy and microalgal exposure, in April (A) and May (B) experiments. indicates statistically significant difference between microalgal exposures (MANOVA).

In April, the reserve/structure ratio was significantly lower (Figure 43) in triploid oysters exposed to A. minutum as compared to triploids fed T.Iso ( $\mathrm{p}=0.0427$, T-test). Exposure to $A$. minutum similarly resulted in a significant decrease of this ratio in diploids in May $(\mathrm{p}=0.0067$, T-test).
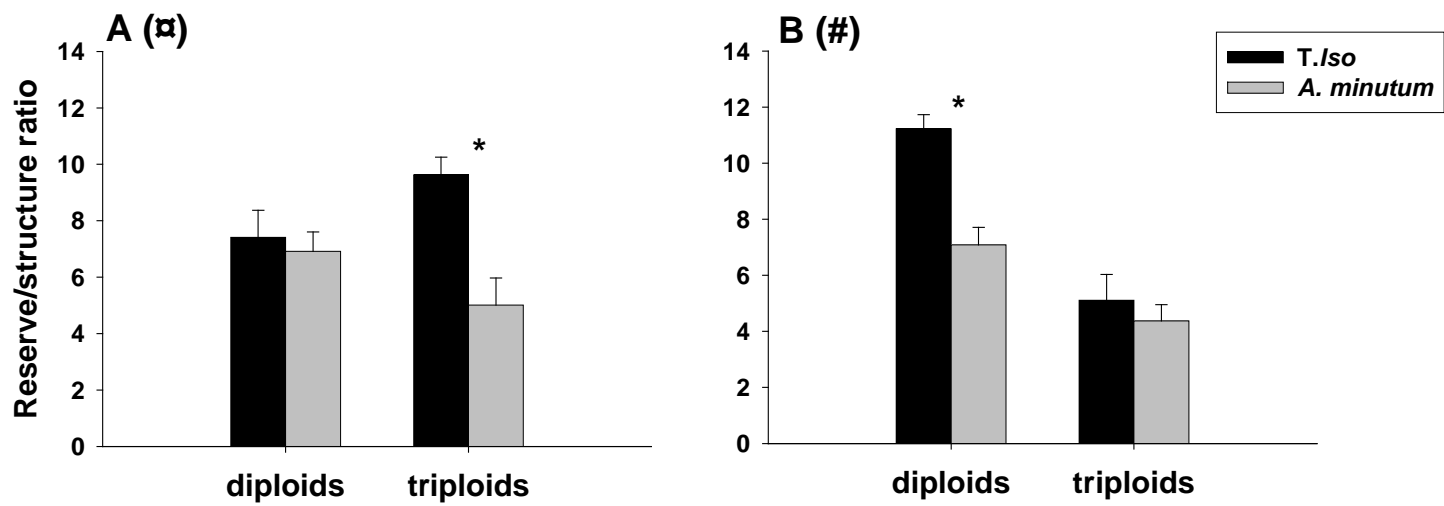

Figure 43 - Ratio between reserve (sterol ester + glycerid ether + triacylglycerol content) and structural (sterol content) lipids $( \pm \mathrm{Cl}$ ) in oyster digestive glands according to ploidy and microalgal exposure, in April (A) and May (B) experiments. \# and indicate statistically significant differences according to ploidy or microalgal exposure, respectively (MANOVA); * indicates statistically significant difference according to microalgal exposure (T-test).

\section{Amylase-specific activity}

Amylase-specific activity (ASA) was significantly higher in May than in April ( $\mathrm{p}=0.0222$, Ttest) (Figure 44). In both experiments ASA was higher in triploids than in diploids (April experiment $\mathrm{p}=0.0263$; May experiment $\mathrm{p}=0.0134$, MANOVA). ASA was higher in $A$. minutum-exposed than in control, diploid oysters in April ( $\mathrm{p}=0.0467$, T-test), but was similar 
in exposed and non-exposed triploid oysters. In May, only triploid oysters showed a significant increase of ASA upon A. minutum exposure ( $\mathrm{p}=0.0337$, T-test).
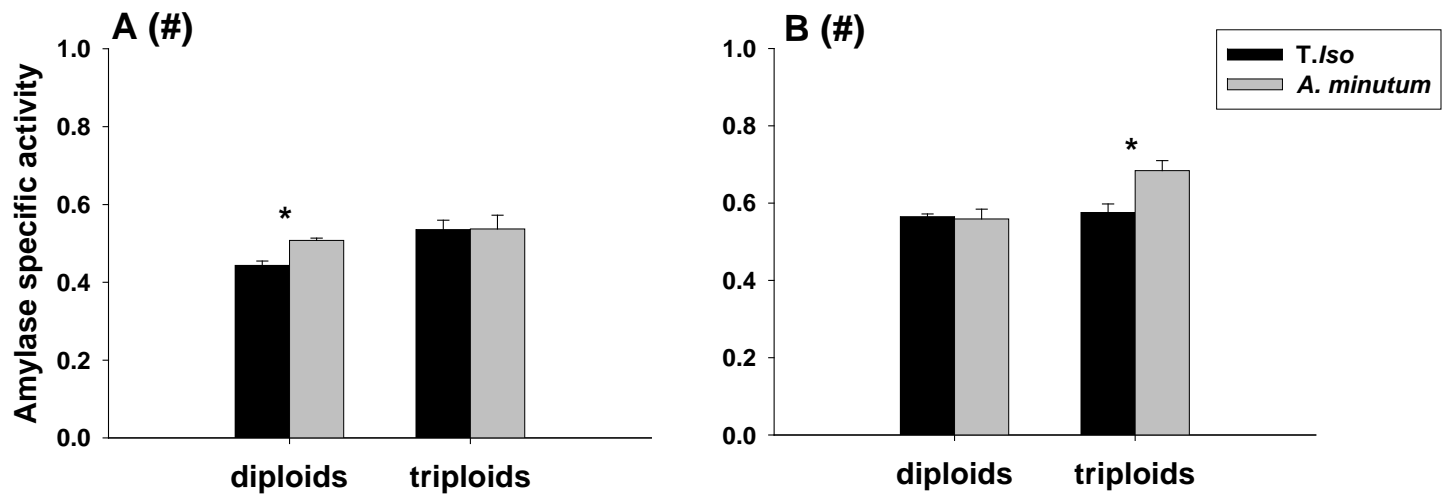

Figure 44 - Amylase-specific activity (mean of 3 pools of 4 oysters each, $\pm \mathrm{Cl}$ ) in oyster digestive glands according ploidy and microalgal exposure, in April (A) and May (B) experiments. \# indicates statistically significant difference according to ploidy (MANOVA); * indicates statistically significant difference according to microalgal exposure (T-test).

\section{Hemocyte and plasma variables}

Overall, ploidy had more significant impacts on hemocyte and plasma variables than algal exposure (Tableau 10).

Tableau 10 - Effects of ploidy and microalgal exposure on oyster hemocyte and plasma variables, tested by MANOVA in April and May experiments.

\begin{tabular}{|c|c|c|c|c|c|c|}
\hline \multirow[b]{2}{*}{ variables } & \multicolumn{3}{|c|}{ April experiment } & \multicolumn{3}{|c|}{ May experiment } \\
\hline & ploidy & diet & interaction & ploidy & diet & interaction \\
\hline concentration of granulocytes & * & ** & NS & NS & NS & NS \\
\hline concentration of agranulocytes & ** & NS & NS & * & NS & NS \\
\hline concentration of agregats & * & NS & NS & $\star \star$ & NS & NS \\
\hline size of granulocytes & * & NS & NS & $\star \star \star *$ & ** & NS \\
\hline size of hyalinocytes & ** & NS & NS & $\star \star \star \star ~$ & ** & NS \\
\hline complexity of granulocytes & NS & NS & NS & $\star \star \star \star ~$ & NS & NS \\
\hline complexity of hyalinocytes & NS & NS & NS & 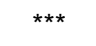 & * & NS \\
\hline arcin (\% phagocytic hemocytes) & NS & NS & NS & $\star \star \star \star ~$ & NS & NS \\
\hline ROS production of granulocytes & ** & * & NS & ** & ** & NS \\
\hline ROS production of hyalinocytes & * & NS & NS & NS & * & NS \\
\hline hemocyte phenoloxidase SA & * & * & NS & * & NS & NS \\
\hline
\end{tabular}

Significant differences are indicated by * when $p<0.05$, ** when $p<0.01$, *** when $p<0.001$; NS non-significant. The following variables were not presented in this table as these were not significantly affected by ploidy ( microalgal exposure or the interaction (MANOVA): concentration of total hemocytes, concentration ( hyalinocytes, \% of dead hemocytes, and plasma variables (phenoloxydase specific activity, agglutination tite and hemolysis titer)

\section{Hemocyte characteristics and functions analyzed by flow cytometry}

Total hemocyte concentration (THC) was significantly higher in May than in April ( $p=0, T-$ test). THC increased significantly upon $A$. minutum exposure in diploid oysters in the April experiment $(p=0.013$, T-test) and triploid oysters in the May experiment ( $p=0.042$ with 
$\alpha=0.05$, T-test) (Figure 45). This increase was mainly attributable to variation in granulocyte counts, especially in April when granulocyte counts drastically increased upon A. minutum exposure.

Sizes (FSC) of granulocytes and hyalinocytes (Figure 45) of oysters in the April experiment were significantly higher in triploids than in diploids, but hemocyte size was not affected by $A$. minutum exposure. In May, size and complexity (SSC) of both granulocytes and hyalinocytes were higher in triploids than in diploids. In the same experiment, A. minutum resulted in a significant increase in granulocyte and hyalinocyte size and in hyalinocyte complexity.
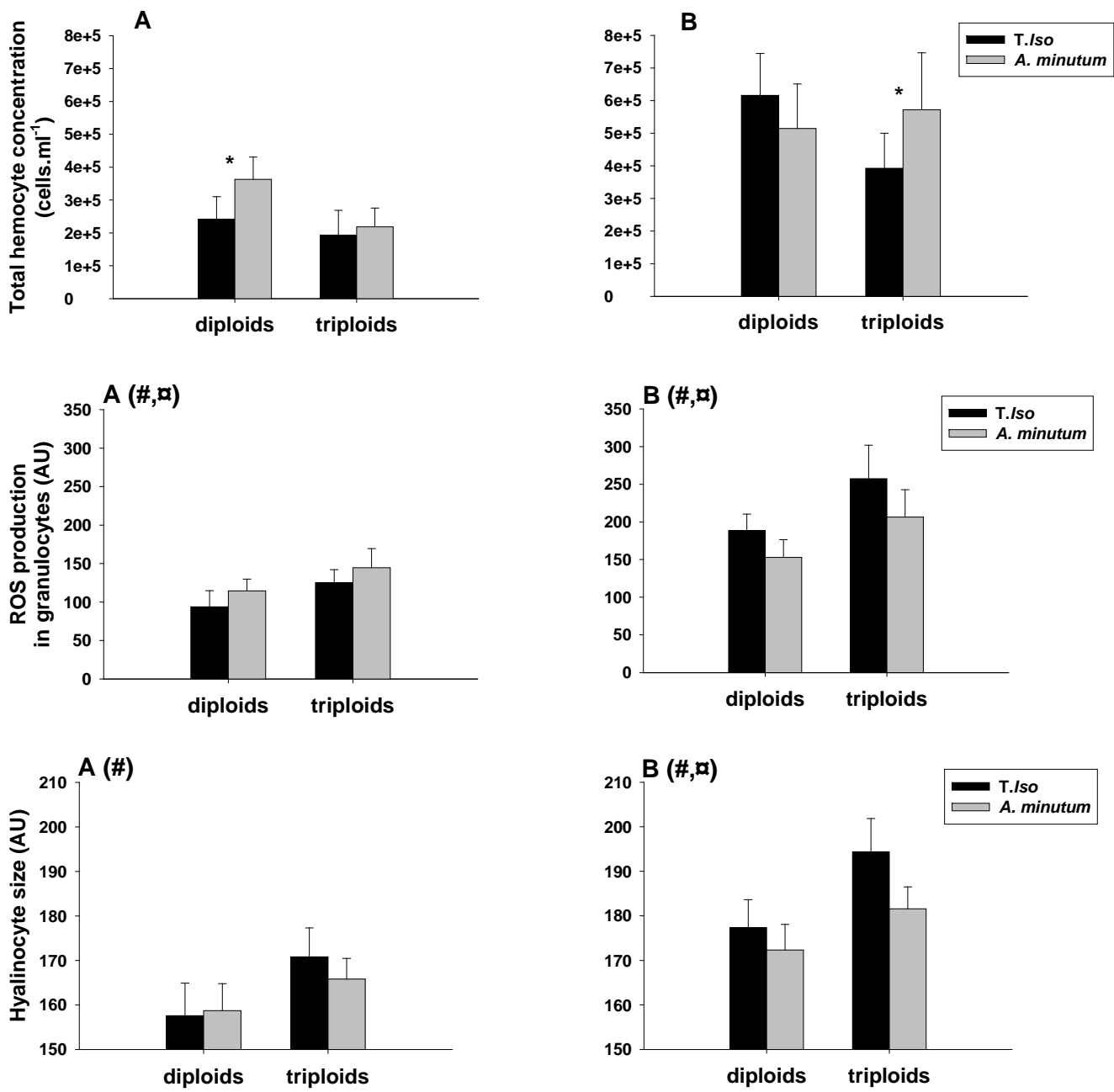

Figure 45 - Total hemocyte count (in cells. $\mathrm{ml}^{-1}$ ), ROS production in granulocytes (AU), and size of hyalinocytes $(\mathrm{AU})$ according to ploidy and microalgal exposure in April (A) and May (B) experiments (mean of 12 individual oysters, $\pm \mathrm{Cl}$ ). \# and indicate statistically significant differences according to ploidy and microalgal exposure, respectively (MANOVA); * indicates statistically significant difference according to microalgal exposure (T-test).

ROS production in granulocytes and hyalinocytes (Figure 45) was significantly higher in May than in April ( $\mathrm{p}=0.0002$ for granulocytes and $\mathrm{p}=0.0011$ for hyalinocytes, T-test). In both experiments, granulocytes of triploids produced more ROS than granulocytes of diploids ( $\mathrm{p}=0.0034$ in April and $\mathrm{p}=0.0012$ in May, MANOVA). The same difference was observed for hyalinocytes but was only significant in April ( $\mathrm{p}=0.0215$, MANOVA). 
A. minutum exposure resulted in opposite effects in the two experiments. In the April experiment, granulocytes of oysters fed $A$. minutum produced more ROS than those of control oysters ( $\mathrm{p}=0.0119$, MANOVA). In the May experiment, granulocytes and hyalinocytes of oysters fed $A$. minutum produced less ROS than those of control oysters ( $p=0.0067$ and $\mathrm{p}=0.0358$ respectively, MANOVA).

Neither phagocytosis nor percentage of dead cells was affected by algal exposure or ploidy.

\section{Hemocyte and plasma phenoloxidase (PO) activities}

PO in plasma was higher in April than in May ( $\mathrm{p}=0.001$, T-test). In April, PO in plasma decreased in A. minutum-exposed oysters, significantly only for diploids ( $\mathrm{p}=0.008$, T-test). There were no significant variations in PO in plasma in May. In hemocytes, PO (Figure 46) was significantly higher in May than in April ( $p=0.0152$, T-test). PO in hemocytes was higher in triploids than in diploids in both April and May experiments (respectively $\mathrm{p}=0.0108$ and $\mathrm{p}=0.046$, MANOVA). In April, PO in hemocytes was lower in oysters fed A. minutum than in control oysters ( $\mathrm{p}=0.0312$, MANOVA). In May, PO in hemocytes was higher in diploids fed A. minutum as compared to control diploids ( $\mathrm{p}=0.0189$, T-test) and lower in triploids ( $\mathrm{p}=0.0458$, T-test).
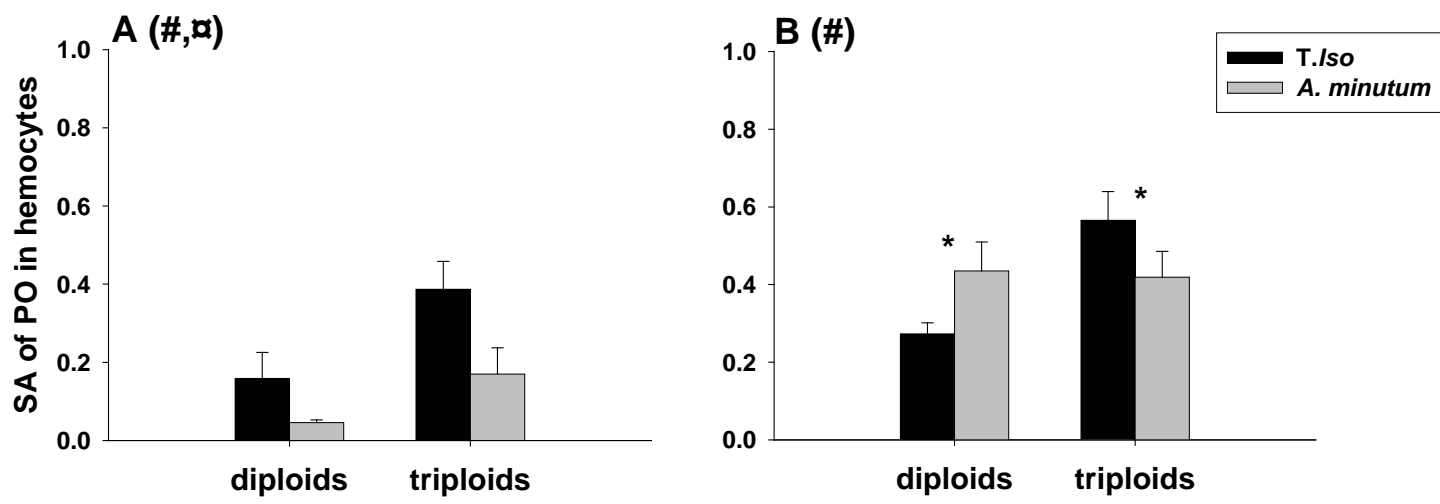

Figure 46 - Specific activity (SA) of phenoloxidase (PO) in hemocytes (mean of 12 individual oysters $\pm \mathrm{Cl}$ ) according to ploidy and microalgal exposure, in April (A) and May (B) experiments. \# and indicate statistically significant differences according to ploidy and microalgal exposure, respectively (MANOVA); * indicates statistically significant difference according to microalgal exposure (T-test).

Agglutination and hemolysis

There were no significant differences in agglutination or hemolysis titer according to algal exposure or ploidy.

\subsubsection{Discussion}

The effects of Alexandrium minutum exposure for 4 days, specifically on toxin accumulation and several physiological parameters, were evaluated in diploid and triploid Pacific oysters, Crassostrea gigas. Although triploid oysters are increasingly used for aquaculture, it was unknown how triploidy may affect toxin accumulation and physiological responses to harmful algal blooms. Two experiments were conducted during two consecutive months to assess the 
possible impact of reproductive stage on toxin accumulation and physiological responses to $A$. minutum exposure. As A. minutum toxins are released in oyster digestive glands, this organ could be expected to be impacted. The second physiological compartment expected to be impacted by A. minutum exposure was the circulatory system, containing hemocytes.

The most striking result in these two experiments was the difference in PST accumulation in digestive glands between diploid and triploid oysters. In both experiments, triploid oysters accumulated twice the toxin of diploids. One could be quick to attribute higher toxin content in triploids to lower gametogenesis, but this hypothesis can be rejected as oysters in the May experiment had both more-advanced gonad development and higher toxin contents than oysters in the April experiment. Gametogenetic stage is not, however, the only trait that distinguishes triploid from diploid oysters. The augmentation in genetic material and gene copies in triploids also has physiological implications by changing heterozygosity. This increased heterozygosity in triploids can lead to additive and non-additive effects upon gene expression (Riddle et al., 2006; Johnson et al., 2007). Indeed, in parallel to toxin accumulation, amylase activity, ROS production, and phenoloxidase activities were found to be higher in triploid oysters than in diploids. Esterase and and peroxidase activities were also found to be higher in triploid oysters than in diploid oysters (Gagnaire et al., 2007). This tends to support the hypothesis that triploids accumulate more toxin than diploids because they are metabolically more active. As triploid heterozygosity is higher, it is thought to have positive influences on feeding rate, absorption efficiency, and growth efficiency (Magoulas et al., 2000). Thus, one can speculate that the difference in toxin accumulation may reflect differences in metabolic and/or feeding activities between diploid and triploid oysters.

The increase in toxin accumulation between April and May experiments is also possibly a result of an increase in feeding and digestive activities. Considering together A. minutumexposed and non-exposed oysters, amylase activity, ROS production, and PO activity were found to be higher in May than in April. Even though oysters in both experiments originated from the same stock and were acclimated for 7 days prior to exposure to A. minutum, an additional month in field rearing conditions appeared to impart subsequent physiological status, including reproductive processes in the conditioned oysters. Indeed, during this additional month, temperature increased from 11 to $15^{\circ} \mathrm{C}$ and photo-period increased from $13 \mathrm{~h} 06$ per day on 5 April to $14 \mathrm{~h} 38$ per day on 2 May. These temperature and photo-period changes allowed diploid oysters to develop from early gametogenesis to a large proportion of mature gonads within one month. This is in good agreement with the study of Fabioux et al. (2005). The percentage of gonad occupation in C.gigas, in field conditions, increased from 15\% to 50\% between April and May (Fabioux et al., 2005). Gonad development and energy allocation in the scallop Pecten maximus were shown to be modulated by temperature and photoperiod (Saout et al, 1999). Similarly Fabioux et al. (2005) experimentally demonstrated that the gametogenic cycle of $C$. gigas can be controlled by coupled modifications of temperature and photoperiod. In marine invertebrates, it is postulated that the nervous system under environmental finfluences has an effect on the endocrine regulation of reproduction (Olive, 1995, Lafont, 2000). In bivalves, fluctuations of neurotransmitters (monoamines) appeared to be related to seasonality and reproductive cycle (Lopez-Sanchez et al., 2009). 
Although specific functions of monoamines are not clearly identified yet, they are thought to be involved in meiosis re-initiation in bivalve oocytes (Guerrier et al., 1993), control of ciliary movement (Carroll and Catapane, 2007), or spawning induction (Velez et al., 1990, Fong et al. 1996, Velasco et al., 2007).

In the present study, the general increase in measured physiological parameters is certainly determined by environmental conditions (temperature, salinity and food in the field) and we speculate that metabolism is further maintained during the experiment possibly through endocrine control. From all the above, we infer that increasing toxin accumulation paralleled increasing metabolic and physiological activities determined by ploidy and preceding field conditions.

Major changes in free fatty acids (FFA), monoacylglycerols (MAG) and diacylglycerols (DAG) contents in the oyster digestive gland were clearly attributable to algal exposure. In both experiments, concentrations of FFA, MAG and DAG were reduced upon A. minutum exposure in both diploids and triploids. These compounds are generally absent in gonad and muscle, and only transiently observed in digestive glands of oysters (Soudant et al., 1999). The biological significance of FFA, DAG and MAG contents is still unclear as little has been published on the subject. These lipid classes are thought to be intermediate products in the synthesis or catabolism of both structural and reserve lipids.

Upon exposure to A. minutum, the ratio of reserve lipids (TAG, EGLY and SE) to structural lipids (sterols) decreased in both experiments. This depletion of reserve lipids upon $A$. minutum exposure, however, appeared to partially depend upon maturation stage. The mostdrastic decrease upon $A$. minutum exposure occurred when oyster gametogenesis was almost absent (April experiment triploids) or predominantly terminated (May experiment diploids). In these physiological conditions, more reserve lipids resided in the digestive gland, where these energy reserves are potentially available to respond to stressful conditions. In contrast, when oysters were in late gametogenesis (April experiment diploids and May experiment triploids), reserve lipids were likely intensively transferred to the gonad and may thus be only slightly affected by A. minutum exposure.

As FFA, MAG and DAG concomitantly decreased with the reserve/structure ratio, we speculate that $A$. minutum negatively affects digestion of dietary lipids and/or synthesis of storage lipids. Also, it has to be noted that contents of TAG and EGLY in A. minutumexposed oysters decreased as toxin accumulation increased according to oyster groups. Nevertheless, at this stage, it is difficult to establish clear relationships between reserve lipid changes and toxin accumulation. To further progress on these aspects, it would be interesting to combine this biochemical information with histological analyses.

Amylase-specific activity (ASA) was also modulated upon A. minutum exposure. Overall, ASA was higher in oysters exposed to A. minutum than in T.Iso-fed oysters, but also higher in triploids than in diploids. As mentioned earlier, ASA, along with other metabolic activities, could partially explain the differences in toxin accumulation between diploids and triploids and between April and May experiments. Digestive-enzyme activities are important in maximizing absorption and food conversion efficiencies (Huvet et al., 2003). In C. gigas, a 
positive correlation has been established between high specific amylase activity and high food assimilation (Prudence et al., 2006). In the present study, digestive-enzyme activities were likely controlled by physiological status, which varied with ploidy and times of experiments. Thus, we speculate that higher amylase activity would result in higher A. minutum digestion and toxin release and assimilation.

These results highlight the complexity of relationships between oyster physiology and toxin accumulation. Toxin accumulation certainly depends upon the physiological status and metabolic activities of the oysters; concomitantly, toxin accumulation can interfere with the same physiological processes.

Regarding hemocyte variables, changes upon A. minutum exposure were mainly observed in hemocyte cell density, phenoloxidase, and ROS production. Except in mature oysters (diploids in experiment 2), A. minutum exposure resulted in increases in numbers of circulating hemocytes. Increase in total circulating hemocyte counts is generally considered to be an immune response to pathogens (Chu et al., 1993; Chu and La Peyre, 1993; Ford et al., 1993; Anderson et al., 1995). Many toxic chemicals can modulate densities of circulating hemocytes, which may increase or decrease according to chemical characteristics and concentrations (Auffret et al., 2002; Gagnaire, 2005; Auffret et al., 2006). Further, modulation of hemocyte counts upon A. minutum exposure appeared to vary according to maturation stage of the oysters. Indeed, mature diploid oysters responded in an opposite manner compared to other oyster groups by decreasing hemocyte count upon A. minutum exposure. Ripe oysters are known to be especially sensitive to stress and to summer mortality (Samain et al., 2007). A. minutum exposure, serving as an additional stress to reproductive effort, may have re-enforced the decrease in hemocyte counts occasionally observed in fully-mature oysters (Delaporte et al., 2006). This makes changes of hemocyte concentration difficult to interpret. The strongest increase in hemocyte concentration occurred in the oyster groups showing the strongest increase in amylase activity upon $A$. minutum exposure. Hemocytes have been thought for a long time to be involved in digestion processes and digestive activities (Cheng, 1996). The observed parallel between hemocyte counts and amylase activities may simply reflect involvement of hemocytes in microalgal digestion and nutrient assimilation.

Reactive oxygen species (ROS) production and phenoloxidase (PO) specific activity in circulating cells were both affected by A. minutum exposure. ROS production is associated with internal chemical destruction of engulfed pathogens or foreign particles within hemocytes (Cheng, 1996; Cheng, 2000; Chu, 2000). Hemocyte ROS production may also be activated by high reproductive effort, leading some to consider reproductive activity as a physiological stress (Delaporte et al., 2006; Delaporte et al., 2007). The elevated energy demand for gamete production leads to a marked increase of whole-animal oxygen consumption during gametogenesis, corresponding to an elevated basal metabolism (Shumway et al., 1988). ROS production was thus hypothesized to reflect an oxidative stress during periods of high energy expenditure, such as active gametogenesis. ROS production was previously observed to increase in ripening oysters, especially in oysters known to be genetically more sensitive to summer mortalities (Delaporte et al., 2007). In the present study, ROS production was two times higher in oysters in the May experiment than in the April 
experiment. This suggests that ROS production may reflect increases in metabolic activities and energy expenditure formerly "programmed" by temperature and photo-period conditions of their rearing site. Temperature and photo-period may accelerate metabolic activities, even for triploid oysters which produced only few mature gametes and remained on average at intermediate stages of gametogenesis.

Upon A. minutum exposure, hemocyte ROS production significantly increased in the April experiment and significantly decreased in the May experiment, similarly in diploid and triploid oysters. In the April experiment, the increase in ROS production may reflect an increase in metabolic activities responding to A. minutum exposure. On the contrary, in the May experiment, we speculate that higher toxin accumulation exceeded the "tolerance" of oysters, affecting directly and more profoundly physiological and metabolic activities leading to reduced ROS production. At this point, we can only confidently conclude that changes in ROS production upon A. minutum exposure do not depend directly upon reproductive activities, as near fully-matured diploid oysters responded similarly to early-maturing triploid oysters. Also, as oysters in the May experiment accumulated twice the toxin of those in the April experiment, we cannot disprove the possibility that released toxins may act as a stimulant when present at low levels, while resulting in inhibitory effects when accumulated at higher concentrations. Similar observations were made in ecotoxicological studies assessing impacts of toxic chemicals upon immune functions in bivalves (Auffret and Oubella, 1997; Fournier et al., 2001; Auffret et al., 2002; Gagnaire et al., 2006). Several heavy metals were demonstrated to have a stimulatory effect upon hemocyte counts, chemotaxy, and mobility in field study. In contrast, in experimental studies, high concentrations of the same heavy metals were inhibitory to the same or related immune parameters (Auffret et al., 2002).

Phenoloxidase is activated by microbial substances and is thought to have a role in host defense in C. gigas (Hellio et al., 2007). PO specific activity was drastically reduced upon $A$. minutum exposure in both diploid and triploid oysters in the April experiment, but PO increased in diploids and decreased in triploids in the May experiment. Thus, mature diploid oysters respond in an opposite manner, compared to other oyster groups, to A. minutum exposure. A. minutum challenge seems to decrease the activity of PO in hemocytes from oysters at early and intermediate maturation stages, and to increase activity in oysters with advanced maturation. Notably, PO activity decreased upon A. minutum exposure when concomitantly hemocyte counts increased. This suggests that hemocytes newly mobilized in the circulatory system may not be fully functional and are less able to produce PO activity.

Triploid oyster hemocytes were significantly larger (higher FSC) than those of diploid hemocytes, possibly because of their higher nuclear DNA content. Additionally, triploid oyster hemocytes were also more complex (higher SSC) than diploid hemocytes. As cell complexity is related to granule content, higher granule content in triploid hemocytes may parallel the higher hemocyte activities (ROS production as well as PO activity).

Triploid oysters were previously reported to have statistically-higher hemocyte phagocytosis, esterase, and peroxidase activities than diploid oysters (Gagnaire et al., 2007). If higher hemocyte chemical activities can confer a better tolerance to toxin accumulation, then triploid 
oysters may have a better ability to respond to A. minutum exposure than diploid oysters. As low toxin sensitivity results in high toxin accumulation (Bricelj and Shumway, 1998), triploids would be able to accumulate more toxin than diploids. Triploid hemocyte size and complexity were reduced upon A. minutum exposure in the May experiment but not in the April experiment. We therefore speculate that toxin accumulation was high enough to affect cell physiology, possibly through cell degranulation, upon toxin exposure.

To summarize, hemocyte responses to in vivo A. minutum exposure depended upon reproductive status, toxin accumulation, but also upon oyster physiological status in the field prior to collection for experiments. When considering only A. minutum-exposed oysters, positive linear correlations between PST accumulation and both hemocyte ROS production (granulocytes: $\mathrm{R}^{2}=0.55, \mathrm{p}<0.01$; hyalinocytes: $\mathrm{R}^{2}=0.6, \mathrm{p}<0.005$ ) and $\mathrm{PO}$ activity (total hemocytes: $\mathrm{R}^{2}=0.74, \mathrm{p}<0.005$ ) were found (data not shown). These relationships indicate that these activities can be considered as good "markers" of metabolic activity useful in interpretation of physiologically-dependent differences in toxin accumulation. As stated above, however, these oxidative activities also may be modulated by other sources of stress, such harmful algae. Thus, it is difficult to unravel the respective influences of physiological status $v s$ stress encountered by oysters.

Bivalve physiological responses to Alexandrium spp. exposure often are thought to be related to toxins (saxitoxin and derivates) affecting human health. It is not known, however, if these compounds are the ones affecting bivalves, or if other compounds produced by harmful algae can affect shellfish at a greater extent. Lush et al. (1997) reported that juvenile greenback flounder (Rhombosolea taparina) exposed to an A. minutum whole cell suspension showed gill damage characterized by severe epithelial swelling that was not related to PSTs. In addition to this ichthyotoxic effect of $A$. minutum, it has been reported that $A$. minutum showed potent toxic effects upon brine shrimp (Artemia salina) (Lush et al., 1996) and a harpacticoid copepod (Euterpina acutifrons) (Bagoien et al., 1996), independently of paralytic-toxin effects. Moreover, Ford et al. (2008) found no measurable effect of a PSTproducing strain of Alexandrium tamarense on hemocytes of two bivalve species. Instead, extract from a non-PST-producing strain had a strong and consistent negative effect on hemocytes from two clam species, resulting in significantly-lower adherence and phagocytosis compared to a PST-producing strain and filtered seawater controls. These studies allow us to suggest that PSTs are not the only compounds responsible of $A$. minutum effects upon oyster physiology, but other active compounds are likely bio-active as well.

\subsubsection{Conclusion}

The most striking result of this study was the difference in PST accumulation between diploid and triploid oysters: triploids accumulate about twice the toxin as diploids. This difference may be attributable to differences in physiology linked to ploidy, especially during reproduction. This finding can have important implications, in terms of oyster production and risk management. 
Despite the finding that $A$. minutum exposure was not lethal to oysters, exposure to a toxinproducing microalga can significantly impact oyster physiology, as compared to non-toxic algae (T.Iso). A. minutum exposure affected several digestive and hematological parameters, and these responses were modulated by ploidy and maturation stage. We highlight, however, that observed effects of $A$. minutum were not only related to PSTs, but likely also to other bioactive compounds produced by $A$. minutum.

Results of the present study showed that analyses of digestive-gland activities and composition (neutral lipids for example) can provide information on effects of $A$. minutum exposure upon oysters. Also, it could be productive to investigate other lipid classes, such as cell membrane constituents (polar lipids). Finally, biochemical approaches developed here can be complementary to histo-pathological observations as such methods have been successfully applied to assess impacts of toxic microalgae upon mollusks (Galimany et. al, 2008).

\section{Acknowledgments}

We thank Isabelle Queau, Luc Lebrun, René Robert, Jean Yves Quillay, Aimé Langlade, Edouard Bédier, Claudie Quere, Florence Royer, Aurélie Lelong and Sébastien Chouinard for their help conducting the experiments and their technical assistance. Sincere thanks are due to Gary H. Wikfors for English corrections. This study was carried out with the financial support of the National Research Agency (ANR), "MODECOPHY" project 06SEST23 (2006-2009).

\section{References}

Anderson, R.S., Burreson, E.M., Paynter, K.T., 1995. Defense responses of hemocytes withdrawn from Crassostrea virginica infected with Perkinsus marinus. J. Invertebr. Pathol. 66, 82-89.

Arzul, G., Seguel, M., Guzman, L., Erard-Le Denn, E., 1999. Comparison of allelopathic properties in three toxic Alexandrium species. J. Exp. Mar. Biol. Ecol. 232, 285-295.

Association of Official Analytical Chemists (AOAC), 1990. Paralytic shellfish poison. Biological method 959.08. In Hellrich, K. (Ed.), Official Methods of Analysis of AOAC INTERNATIONAL., Arlington, VA, pp.881-882

Auffret, M., Rousseau, S., Boutet, I., Tanguy, A., Baron, J., Moraga, D., Duchemin, M., 2006. A multiparametric approach for monitoring immunotoxic responses in mussels from contaminated sites in western mediterranea. Ecotox. Environ. Safe. 63, 393-405.

Auffret, M., Mujdzic, N., Corporeau, C., Moraga, D., 2002. Xenobiotic-induced immunomodulation in the European flat oyster, Ostrea edulis. Mar. Environ. Res. 54, 585589.

Auffret, M., Oubella, R., 1997. Hemocyte aggregation in the oyster Crassostrea gigas: In vitro measurement and experimental modulation by xenobiotics. Comp Biochem Physiol Physiol. 118, 705-712.

Auffret, M. and Oubella, R., 1995. Cytological and cytometric analysis of bivalves molluscs hemocytes, in: (Eds: Stolen, J.S., Fletcher, C., Smith, S.A., Zelikoff, J.T., Kaattari, S.L., Anderson, R.S., Soderhall, K. \& Weeks-Perkins, B.A.). Fair Haven: SOS Publication. 
Bagoien, E., Miranda, A., Reguera, B., Franco, J.M., 1996. Effects of two paralytic shellfish toxin producing dinofagellates on the pelagic harpacticoid copepod Euterpina acutifrons. Mar. Biol. 126, 361-369.

Bardouil, M., Bohec, M., Cormerais, M., Bougrier, S., Lassus, P., 1993. Experimental study of the effects of a toxic microalgal diet on feeding of the oyster Crassostrea gigas Thunberg. J. Shellfish Res. 12, 417-422.

Barracco, M.A., Medeiros, I.D., Moreira, F.M., 1999. Some haemato-immunological parameters in the mussel Perna perna. Fish Shellfish Immunol. 9, 387-404.

Bricelj, V.M., Connell, L., Konoki, K., Mac-Quarrie, S.P., Scheuer, T., Catterall, W.A., Trainer, V.L., 2005. Sodium channel mutation leading to saxitoxin resistance in clams increases risk of PSP. Nature 434, 763-767.

Bricelj, V.M., Shumway, S.E., 1998. Paralytic shellfish toxins in bivalve molluscs: occurrence, transfer kinetics, and biotransformation. Res. Fish. Sci. 6, 315-383.

Carroll, M.A., Catapane, E.J., 2007. The nervous system control of lateral ciliary activity of the gill of the bivalve mollusc Crassostrea virginica. Comp. Biochem. Physiol. A Mol. Integr. Physiol. 148, 445-450.

Chang, F.H., Anderson, D.M., Kulis, D.M., Till., D.G., 1997. Toxin production of Alexandrium minutum (dinophyceae) from the Bay of Plenty, New Zealand. Toxicon 35, 393-409.

Cheng, T.C., 2000. Cellular defense mechanisms in oysters. In: Fingerman, M., Nagabhushanam, R. (eds) Recent Advances in Marine Biotechnology. Enfield: Science Publishers Inc. Vol. 5, 43-83.

Cheng, T.C., 1996. Hemocytes: Forms and functions. In: The Eastern Oyster Crassostrea virginica (V.S. Kennedy, R.I.E. Newell, \& A.F. Eble, eds.), pp. 299- 333. Maryland Sea Grant, College Park, MD, USA.

Chou, H.N., Chen, Y.M., Chen, C.Y., 2004. Variety of PSP toxins in four culture strains of Alexandrium minutum collected from southern Taiwan. Toxicon 43, 337-340.

Chu, F.L.E., 2000. Defense mechanisms of marine bivalves. In: Fingerman, M., Nagabhushanam, R. (eds) Recent Advances in Marine Biotechnology. Enfield: Science Publishers Inc. Vol. 5. pp. 1-42.

Chu, F.L.E., La Peyre, J.F., 1993. Perkinsus marinus susceptibility and defense-related activities in eastern oysters Crassostrea virginica: temperature effects, Dis. Aquat. Org. 16, 223-234.

Chu, F.L.E., La Peyre, J.F., Burreson, C.S., 1993. Perkinsus marinus infection and potential defense-related activities in eastern oysters, Crassostrea virginica: salinity effects. J. Invertebr. Pathol. 3, 226-232.

Delaporte, M., Chu, F.L., Langdon, C., Moal, J., Lambert, C., Samain, J.F., Soudant, P., 2007. Changes in biochemical and hemocyte parameters of the Pacific oysters Crassostrea gigas fed T.Iso supplemented with lipid emulsions rich in eicosapentaenoic acid. J. Exp. Mar. Biol. Ecol. 343, 261-275.

Delaporte, M., Soudant, P., Lambert, C., Moal, J., Pouvreau, S., Samain, J.F., 2006. Impact of food availability on energy storage and defense related hemocyte parameters of the Pacific oyster Crassostrea gigas during an experimental reproductive cycle. Aquaculture 254, 571-582. 
Delaporte, M., Soudant, P., Moal, J., Lambert, C., Quere, C., Miner, P., Choquet, G., Paillard, C., Samain, J.F., 2003. Effect of a mono-specific algal diet on immune functions in two bivalve species - Crassostrea gigas and Ruditapes philippinarum. J. Exp. Biol. 206, 3053-3064.

EFSA Journal, 2009. Scientific Opinion of the Panel on Contaminants in the Food Chain on a request from the European Commission on Marine Biotoxins in Shellfish - Summary on regulated marine biotoxins. 1306, 1-23.

Emura, A., Matsuyama, Y., Oda, T., 2004. Evidence for the production of a novel proteinaceous hemolytic exotoxin by dinoflagellate Alexandrium taylori. Harmful Algae 3, $29-37$.

Fabioux, C., Huvet, A., Le Souchu, P., Le Pennec, M., Pouvreau, S., 2005. Temperature and photoperiod drive Crassostrea gigas reproductive internal clock. Aquaculture. 250, 458470.

Fernández-Reiriz, M.J., Navarro, J.M., Contreras, A.M., Labarta, U., 2008. Trophic interactions between the toxic dinoflagellate Alexandrium catenella and Mytilus chilensis: Feeding and digestive behaviour to long-term exposure. Aquat. Toxicol. 87, 245-251.

Fernández, M.L., Shumway, S., Blanco, J., 2003. Management of shellfish resources. In: Manual on Harmful Marine Microalgae. G.M. Hallegraeff, M. Anderson, A.D Cembella (eds.). IOC Manuals and Guides, UNESCO, pp 657-692.

Fong, P.P., Deguchi, R., Kyozuka, K., 1996. Serotonergic ligands induce spawning but not oocyte maturation in the bivalve Mactra chinensis from central Japan. Biol. Bull. 191, $27-32$.

Ford, S.E., Bricelj, V.M., Lambert, C., Paillard, C., 2008. Deleterious effects of a nonPST bioactive compound(s) from Alexandrium tamarense on bivalve hemocytes. Mar. Biol. 154, 241-253.

Ford, S.E., Kanaley, S.A., Littlewood, D.T.J., 1993. Cellular Responses of Oysters Infected with Haplosporidium nelsoni: Changes in Circulating and Tissue-Infiltrating Hemocytes. J. Invertebr. Pathol. 61, 49-57.

Fournier, M., Pellerin, J., Clermont, Y., Morin, Y., Brousseau, P., 2001. Effects of in vivo exposure of Mya arenaria to organic and inorganic mercury on phagocytic activity of hemocytes. Toxicology 161, 201-211.

Gagnaire, B., Soletchnik, P., Faury, N., Kerdudou, N., Le Moine, O., Renault, T., 2007. Analysis of hemocyte parameters in Pacific oysters, Crassostrea gigas, reared in the field. Comparison of hatchery diploids and diploids from natural beds. Aquaculture 264, 449-456.

Gagnaire, B., Thomas-Guyon, H., Burgeot, T., Renault, T., 2006. Pollutant effects on Pacific oyster, Crassostrea gigas (Thunberg), hemocytes: Screening of 23 molecules using flow cytometry. Cell Biol. Toxicol. 22, 1-14.

Gagnaire, B., 2005. Etude des effets de polluants sur les paramètres hémocytaires de l'huitre creuse, Crassostrea gigas. Interactions entre environnement, mécanismes de défense et maladies infectieuses, Ph.D. thesis, La Rochelle.

Galimany, E., Sunila, I., Hégaret, H., Ramón, M., Wikfors, G.H., 2008. Experimental exposure of the blue mussel (Mytilus edulis) to the toxic dinoflagellate Alexandrium fundyense: Histopathology, immune responses, and recovery. Harmful Algae 7, 702-711.

Guerrier, P., Leclerc-David, C., Moreau, M., 1993. Evidence for the involvement of internal calcium stores during serotonin-induced meiosis reinitiation in oocytes of the bivalve mollusc Ruditapes philippinarum. Dev. Biol. 159, 474-484. 
Guillard, R.R.L., and Hargraves, P.E., 1993. Stichochrysis immobilis is a diatom, not a chrysophyte. Phycologia. 32, 234-236.

Hégaret, H., Shumway, S. E., Wikfors, G.H., 2009. Biotoxin contamination and shellfish safety. In Shumway, S.E. and G.E. Rodrick (eds). Shellfish Safety and Quality, Woodhead Publishing Limited, Cambridge, UK p43-80.

Hégaret, H., Wikfors, G.H., Shumway, S.E., 2008. In vitro interactions between several species of harmful algae and hemocytes of bivalve molluscs. In: Proceedings of the 2007 international harmful algae conference, Copenhagen, Denmark.

Hégaret, H., da Silva, P.M., Wikfors, G.H., Lambert, C., De Bettignies, T., Shumway, S.E., Soudant, P., 2007a. Hemocyte responses of Manila clams, Ruditapes philippinarum, with varying parasite, Perkinsus olseni, severity to toxic-algal exposures. Aquat. Toxicol. 84, 469-479.

Hégaret, H., Wikfors, G., Soudant, P., Lambert, C., Shumway, S., Bérard, J., Lassus, P., 2007b. Toxic dinoflagellates (Alexandrium fundyense and $A$. catenella) have minimal apparent effects on oyster hemocytes. Mar. Biol. 152, 441-447.

Hellio, C., Bado-Nilles, A., Gagnaire, B., Renault, T., Thomas-Guyon, H., 2007. Demonstration of a true phenoloxidase activity and activation of a ProPO cascade in Pacific oyster, Crassostrea gigas (Thunberg) in vitro. Fish Shellfish Immunol. 22, 433-440.

Huss, H.H., 2003. Aquatic biotoxins. Chapter 5.1.5. in Huss, H.H.; Ababouch, L.; Gram, L., Assessment and Management of Seafood Safety and Quality. FAO Fisheries Technical Paper. 239 p.

Huvet, A., Daniel, J.Y., Quéré, C., Dubois, S., Prudence, M., Van Wormhoudt, A. Sellos, D., Samain, J.F., Moal, J., 2003. Tissue expression of two $\alpha$-amylase genes in the pacific oyster Crassostrea gigas. Effects of two different food rations. Aquaculture 228, 321-333.

Johnson, R.M., Shrimpton, J.M., Cho, G.K., Heath, D.D., 2007. Dosage effects on heritability and maternal effects in diploid and triploid Chinook salmon (Oncorhynchus tshawytscha). Heredity 98, 303-310.

Labarta, U., Fernández-Reiriz, M., Navarro, J., Velasco, A., 2002. Enzymatic digestive activity in epifaunal (Mytilus chilensis) and infaunal (Mulinia edulis) bivalves in response to changes in food regimes in a natural environment. Mar. Biol. 140, 669-676.

LaFont, R., 2000. The Endocrinology of Invertebrates. Ecotoxicology 9, 41-57.

Lambert, C., Moal, J., Le Moullac, G., Pouvreau, S., 2008. Mortality risks associated with physiological traits of oysters during reproduction. In: Summer mortality of Pacific oyster Crassostrea gigas. The Morest Project. Samain J.F. and McCombie H. (eds). Ed. Ifremer/Quæ, Versailles, France, pp. 63-106.

Lambert, C., Soudant, P., Choquet, G., Paillard, C., 2003. Measurement of Crassostrea gigas hemocyte oxidative metabolism by flow cytometry and the inhibiting capacity of pathogenic vibrios. Fish Shellfish Immunol. 15, 225-240.

Lassus, P., Amzil, Z., Baron, R., Séchet, V., Barillé, L., Abadie, E., Bardouil, M., Sibat, M., Truquet, P., Bérard, J.B., Gueguen, M., 2007. Modelling the accumulation of PSP toxins in Thau Lagoon oysters (Crassostrea gigas) from trials using mixed cultures of Alexandrium catenella and Thalassiosira weissflogii. Aquat. Living Resour. 20, 59-67. 
Lassus, P., Baron, R., Garen, P., Truquet, P., Masselin, P., Bardouil, M., Leguay, D., Amzil, Z., 2004. Paralytic shellfish poison outbreaks in the Penze estuary: Environmental factors affecting toxin uptake in the oyster, Crassostrea gigas. Aquat. Living Resour. 17, 207-214.

Lassus, P., Bardouil, M., Ledoux M., Murai1, I., Bohec, M., Truquet, P., Frémy, J.-M., Rohmer, V., 1992. Paralytic phycotoxin uptake by scallops (Pecten maximus). Aquat. Living Resour. 5, 319-324.

Le Moine, S., Sellos, D., Moal, J., Daniel, J.Y., San Juan, S.F., Samain, J.F., Van Wormhoudt, A., 1997. Amylase on Pecten maximus (mollusca, bivalves): protein and cdna characterization; quantification of the expression in the digestive gland. Mol. Marine Biol. Biotechnol. 6, 228-237.

Li, S.C., Wang, W.X., Hsieh, D.P.F., 2002. Effects of toxic dinoflagellate Alexandrium tamarense on the energy budgets and growth of two marine bivalves. Mar. Environ. Res. 53, 145-160.

López-Sánchez, J.A., Maeda-Martínez, A.N., Croll, R.P., Acosta-Salmón., H., 2009. Monoamine fluctuations during the reproductive cycle of the Pacific lion's paw scallop Nodipecten subnodosus. Comp. Biochem. Physiol. A Mol. Integr. Physiol. 154, 425-428.

Lucas, A., Beninger, P.G., 1985. The use of physiological condition indices in marine bivalve aquaculture. Aquaculture. 44, 187-200.

Lush, G.J., Hallegraeff, G.M., Munday, B.L., 1997. Harmful Algae, chap. Histopathological effects in juvenile green black flounder Rhombosolea taparina exposed to the toxic dinoflagellate Alexandrium minutum. Xunta de Galicia and Intergovernmental Oceanographic Commission of UNESCO. pp. 609-610.

Lush, G.J., Hallegraeff, G.M., Munday, B.L., 1996. Harmful and Toxic Algal Blooms, chap. High toxicity of the red tide dinoflagellate Alexandrium minutum to the brine shrimp Artemia salina. Intergovernmental Oceanographic Commission of UNESCO. pp. 389-392.

Magoulas, A., Kotoulas, G., Gerard, A., Naciri-Graven, Y., Dermitzakis, E., Hawkins, A.J.S., 2000. Comparison of genetic variability and parentage in different ploidy classes of the japanese oyster Crassostrea gigas. Genet. Res. 76, 261-272.

Mann, R., 1979. Some biochemical and physiological aspects of growth and gametogenesis in Crassostrea gigas and Ostrea edulis grown at sustained elevated temperatures. J. Mar. Biolog. Assoc. U.K. 59, 95-110.

Marie, D., Partensky, F., Vaulot, D., Brussaard, C., 1999. Current Protocols in Cytometry, chap. Enumeration of phytoplankton, bacteria, and viruses in marine samples, pp. 11.11.11_11.11.15, New York: John Wiley \& Sons Inc.

Martoja, R., Martoja-Pierson, M., Grassé, P.P., 1967. Initiation aux techniques de l'histologie animale. Paris, Masson. pp. 345.

Morin, P., Erard-Le Denn, E., Maguer, J.F., Madec, C., Videau, C., Legrand, J., Macé, E., 2000. Étude des causes de prolifération de microalgues toxiques en mer : cas d'Alexandrium. Final AELB report, Convention 7.98.9476, 135 p.

Narahashi, T., 1988. Mechanism of tetrodotoxin and saxitoxin action. In: Handbook of Natural Toxins. Marine Toxins and Venoms, (A. T. Tiu, Ed.) New York: Marcel Dekker Inc. Vol 3, pp. 185-210. 
Normand, J., Le Pennec, M., Boudry, P., 2008. Comparative histological study of gametogenesis in diploid and triploid pacific oysters (Crassostrea gigas) reared in an estuarine farming site in france during the 2003 heatwave. Aquaculture 282, 124-129.

Olive, P.J.W., 1995. Annual breeding cycles in marine invertebrates and environmental temperature: probing the proximate and ultimate causes of reproductive synchrony. J. rherm. Bid. 20, 79-90.

Oshima, Y., 1995. Postcolumn derivatization liquid chromatographic method for paralytic shellfish toxins. J AOAC Int. 78, 528-532.

Prudence, M., Moal, J., Boudry, P., Daniel, J.Y., Quere, C., Jeffroy, F., Mingant, C., Ropert, M., Bedier, E., Van Wormhoudt, A., Samain, J.F., Huvet, A., 2006. An amylase gene polymorphism is associated with growth differences in the pacific cupped oyster Crassostrea gigas. Anim. Genet. 37, 348-351.

Reid, H.I., Soudant, P., Lambert, C., Paillard, C., Birkbeck, T.H., 2003. Salinity effects on immune parameters of Ruditapes philippinarum challenged with Vibrio tapetis. Dis. Aquat. Org. 56, 249-258.

Riddle, N.C., Kato, A., Birchler, J.A., 2006. Genetic variation for the response to ploidy change in Zea mays. Theor. Appl. Genet. 114, 101-111.

Samain, J.F.,Dégremont, L., Soletchnik, P., Haure, J., Bédier, E., Ropert, M., Moal1, J., Huvet, A., Bacca1, H., Van Wormhoudt, A., Delaporte, M., Costil, K., Pouvreau, S., Lambert,C., Boulo, V., Soudant, P., Nicolas, J.L., Le Roux, F., Renault, T., Gagnaire, B., Geret, F., Boutet, I., Burgeot, T., Boudry, P., 2007. Genetically based resistance to summer mortality in the Pacific oyster (Crassostrea gigas) and its relationship with physiological, immunological characteristics and infection processes. Aquaculture. 268, 227-243.

Samain, J.F., Daniel, J.Y., Le Coz, J.R., 1977. Trypsine, amylase et protéines du zooplancton: dosage automatique et manuel. J. Exp. Mar. Biol. Ecol. 29, 279-289.

Saout, C., Quéré, C., Donval, A., Paulet, Y.-M., Samain, J.-F., 1999. An experimental study of the combined effects of temperature and photoperiod on reproductive physiology of Pecten maximus from the Bay of Brest (France). Aquaculture 172, 301-314.

Shumway, S.E., Sherman-Caswell, S., Hurst, J.W., 1988. Paralytic shellish poisoning in Maine: monitoring a monster. J. Shellfish Res. 7, 643-652.

Soudant, P., Van Ryckeghem, K., Marty, Y., Moal, J., Samain, J.F., Sorgeloos, P., 1999. Comparison of the lipid class and fatty acid composition between a reproductive cycle in nature and a standard hatchery conditioning of the Pacific Oyster Crassostrea gigas. Comp. Biochem. Physiol. B, Biochem. Mol. Biol. 123, 209-222.

Tillmann, U., Alpermann, T., John, U., Cembella, A., 2008. Allelochemical interactions and shortterm effects of the dinoflagellate Alexandrium on selected photoautotrophic and heterotrophic protists. Harmful Algae 7, 52-64.

Velasco, L.A., Barrosa, J., Acosta, E., 2007. Spawning induction and early development of the Caribbean scallops Argopecten nucleus and Nodipecten nodosus. Aquaculture 266, 153 165.

Velez, A., Alifa, E., Azuaje, O., 1990. Induction of spawning by temperature and serotonin in the hermaphroditic tropical scallop, Pecten ziczac. Aquaculture 84, 307-313. 